\title{
Nonwood-Based Composites
}

\author{
M. T. Paridah ${ }^{1}$ - A. H. Juliana ${ }^{1}$ - A. Zaidon $^{1}$ - H. P. S. Abdul Khalil ${ }^{2}$
}

Published online: 2 November 2015

(C) Springer International Publishing AG 2015

\begin{abstract}
Nonwood fibers are derived mostly from fastgrowing plants. For the past few decades, nonwood plant fibers have received much attention, especially for composite material applications, because of their low cost, low density, high specific strength, good mechanical properties, nonabrasiveness, eco-friendliness, and biodegradability. This article reviews the performance of nonwood fibers found mostly in Asia, as well as issues regarding their bonding. Because various classifications of nonwood exist, this article sorts nonwood fibers based on previous classifications with some modifications, accounting for the availability of these fibers in Asia. The mechanical and physical properties of nonwood-based composites such as fiberboard, particleboard, and veneer-based laminated products also are reviewed and discussed. All fibers demonstrate certain advantages over conventional composites, with some having better mechanical and physical properties. This article also highlights the issues and challenges regarding the use of nonwood fibers as composite materials.
\end{abstract}

Keywords Nonwood fibers · Composites · Asian regions · Physical properties $\cdot$ Mechanical properties

This article is part of the Topical Collection on Wood Structure and Function

\section{T. Paridah}

parida.introp@gmail.com

A. H. Juliana

julianahalip@gmail.com

1 Institute of Tropical Forestry and Forest Products, Universiti Putra Malaysia, 43400 UPM Serdang, Selangor, Malaysia

2 School of Industrial Technology, Universiti Sains Malaysia, Gelugor 11800, Penang, Malaysia

\section{Introduction}

Nonwood fibers are one of the important alternative resources for fibrous material in the twenty-first century because of the shortage of trees and increasing global demand for fibrous material [1]. These plant fibers have been receiving tremendous attention for decades, and interest in them is still growing strongly. An example of nonwood fibers is "field crops" or agricultural crops grown for their fibers. Such fibers have existed for hundreds of years and traditionally have been used to make paper, cloth, rope, and composite products, ensuring their continued existence [2]. Bamboo, another example of nonwood found in the forest, has attracted global interest recently. Biomass, on the other hand, is fiber residue derived from plants either at the plantation or at the processing mill. Very often, biomass is associated with biorefinery activities for energy production.

For decades, materials scientists and engineers have been exploring other uses for natural fibers in composite materials. This article reviews the basic properties of some nonwood fibers, particularly those found in Asia, and highlights issues regarding bonding with polymer, surface wettability, buffering capacity, and the influence of these fibers on board properties. The properties of particleboard, fiberboard, laminated board, and plywood manufactured from various types of nonwood fibers are compared.

\section{Types of Nonwood Fibers}

Nonwood plants are either dicotyledonous or monocotyledonous and may be divided into various classifications. Previous studies categorized plant fibers based on their origin and divided them into two main groups $[3 \bullet, 4,5,6 \bullet \bullet]$ : 
Conventional plant fibers, such as cotton, kapok, flax, jute, hemp, ramie, kenaf, sisal, abaca, henequen, coir, and bamboo

Nonconventional plant fibers or agro-based fiber residues, such as corn stalk; wheat straw; rice straw; rice husks; sugarcane/bagasse; pineapple leaf; banana pseudostem; coconut stem; and oil palm fibers from the stem/trunk (OPT), fronds, and empty fruit bunch (EFB)

Most nonwood fibers are derived from plants that are fast growing and require months (kenaf, jute, flax, and hemp) to years (oil palm, coconut, bamboo, abaca, and sisal) to reach maturity. Compared with softwood, which takes more than 20 years, and hardwood, which requires more than 30 years to reach maturity, nonwood growth cycles are significantly shorter [7]. Because of the differences in maturity periods, nonwood fiber plants have various stem sizes: slender, e.g., kenaf, jute, hemp, wheat straw, and bagasse; moderate, e.g., bamboo; and large, e.g., oil palm trunk and coconut trunk. This variation explains why the processing lines used for each type of nonwood fiber differ from one another.

Traditionally, most nonwoods, including bagasse, wheat and rice straw, bamboo, kenaf, hemp, jute, sisal, abaca, cotton linters, and reeds, have been used worldwide to manufacture pulp and paper [8]. Besides their use in papermaking, nonwood plants have served as potential raw materials in value-added panels such as medium-density fiberboard (MDF), particleboard, oriented strand board (OSB), plywood, and laminated products. Some nonwood fibers are being used as reinforcement in the production of wood polymer composites (WPCs). Most of these fibers are processed easily into pulp, particles, strands, and sawdust to produce MDF, particleboard, OSB, and WPC panels, respectively; however, some limitations exist in using them to produce plywood and laminated materials. Except for oil palm trunk and bamboo, most nonwood plants have a relatively small diameter, approximately 1 to $5 \mathrm{~cm}$, making them impractical for processing into veneer, lumber, or strips. In this article, we categorize nonwoods based on their origin as (1) agricultural-based or agro-fibers, (2) plant biomass, or (3) grass. Figure 1 shows some examples of plants based on these categories.

\section{Agro-Fibers}

The most popular and frequently cited agro-fibers belong to a group known as bast fibers. These fibers are derived from plants with established and specific end uses because of their properties. Examples are jute, hemp, flax, kenaf, and ramie. Sisal, abaca, and henequen are other examples of agro-fibers that are derived from leaves $[4,5]$. The presence of these crops usually is linked to a specific country, climate, or culture. Hemp and flax are found mainly in Europe, and sisal is found mainly in Tanzania and Brazil, abaca in the Philippines, and jute in Bangladesh and India [9]. Although China has a unique agricultural practice whereby all types of hard fibers (hemp, flax, ramie, jute, kenaf) have been grown for more than 100 years, planted areas have diminished significantly as a result of an increase in food crop cultivation. Kenaf, on the other hand, is an attractive agro-fiber with a long history of cultivation in the USA, Bangladesh, India, Thailand, Australia, Indonesia, and Malaysia and, to a lesser extent, in southeast Europe, some parts of Africa, and Brazil [10]. In different parts of the world, many other names have been used for kenaf, including mesta (India), java jute (Indonesia), stock root (South Africa), and ambary (Taiwan) [11]. Jute is a long, soft, and shiny fiber that can be spun into coarse, strong threads and is one of the cheapest natural fibers. It also is one of the most versatile, eco-friendly, durable, and antistatic fibers. Normally, jute plants are retted by the same method used for flax [5]. On the international market, the names jute and kenaf are used interchangeably because of their close resemblance.

\section{Plant Biomass}

Coconut trunk and coir, two types of biomass from coconut trees, have been on the market for decades. Whereas the trunk has been used by the timber industry to make laminated products and plywood, coir is the most popular fiber used in manufacturing high-quality mattresses. Sri Lanka and the Philippines are the main exporters of this material. Coir fibers are coarse and short and are extracted from the outer shell of coconuts. Of all the commercial natural fibers, coir is reported to be the most resistant to microbial action and salt water damage. Its low decomposition rate is a key advantage in making durable geotextiles [12].

Oil palm (Elaeis guineensis Jacq.), a monocotyledonous plant, normally presents as a single stem approximately $20 \mathrm{~m}$ in height. Malaysia and Indonesia are the largest producers of palm oil in the world. Traditionally, the main product of oil palm has been palm oil, with the remaining biomass waste either burned (as the main energy source for power generation in palm oil mills) or used as organic fertilizer through natural decomposition $[13,14]$. In addition, EFB is also used in soil mulching as an organic nutrient to reduce the input of inorganic fertilizer [15]. Today, oil palm plantation generates huge amount of biomass in the form of trunks (after a 25-year replantation scheme) and fronds (with every tree pruned once a month). In addition, EFBs are generated from the palm oil factory every day $[16,17]$.

Bagasse, a by-product of sugar milling, is the crushed remnants of sugarcane stalks that remain after the juice is extracted. It consists of three parts - pith, fiber, and rind - mixed in different proportions, with considerable variation in the shape and size of these three components [18]. 


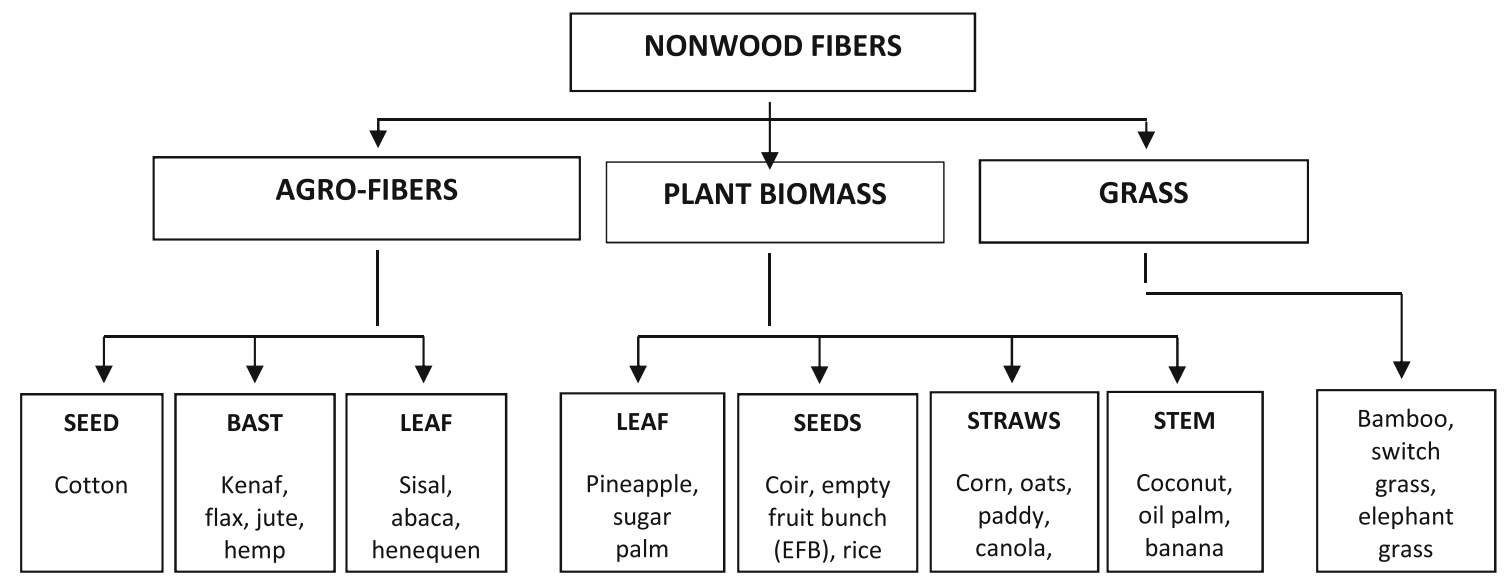

Fig. 1 Classification of nonwood fibers

Straw, an agricultural by-product, is composed of the dry stalks of cereal plants after the grain and chaff have been removed. Straw makes up about half the yield of cereal crops such as barley, oats, rice, rye, and wheat. Currently, there are huge quantities of unused straw residues around the globe. In 1999, China, India, and the USA appeared to be the major producers of straw residues, mainly wheat and rice straws [19]. However, in 2012, Europe was the leading exporter of straw husks at 783,485 t [20]. Straw has many uses, including fuel, livestock bedding and fodder, thatching, and basket making. It usually is gathered and stored in straw bales.

Another agricultural residue of interest is rice husk, a byproduct of rice mills. The husk is the hard protective covering on a rice grain and is available throughout the year. Currently, rice husks are used in many applications, including composites, fertilizer, insulation material, and fuel [21].

\section{Grasses}

Among the many types of grasses, bamboo is the most popular. It has been identified as one of the most promising crops because of its great strength: the strength-to-weight ratio of bamboo is far higher than that of structural steel, aluminum alloy, cast iron, timber, and concrete, proving that it has a very efficient load-bearing capability [22]. Bamboo is a versatile, strong, renewable, and environmentally friendly material. It is a member of the grass family, Gramineae, and the fastestgrowing woody plant on Earth because of its unique rhizome-dependent system [23, 24]. As stated by Chaowana [24], bamboo is distributed mostly in the tropical, subtropical, and temperate zones of all continents except Europe and North America. However, in recent years, bamboo was introduced to North America, Europe, and Australia [25, 26]. Bamboo has a wide range of applications: it is used as a source of food and energy and as a material for handicrafts, construction, and vehicle parts, as well as for ornamental and many other purposes [24, 27].

\section{Properties of Nonwood Fibers}

\section{Bulk Properties}

For all fiber-based products, both density and moisture content are crucial because they determine the actual amount of fibers and resin/matrices to be used. Bulk density is defined as the weight of a cubic meter of a loose volume of fibers, which varies with moisture content [28]. Most nonwood fibers are denser than wood (Table 1); however, most of these fibers, particularly those from biomasses, have greater density variations. For example, bagasse varies from 0.52 to $1.47 \mathrm{~g} / \mathrm{cm}^{3}$ [46] and wheat straw from 0.02 to $1.10 \mathrm{~g} / \mathrm{cm}^{3}$ in density [48]. Bamboo fiber has a higher density than most wood.

\section{Anatomic Properties Specific}

Agro-fibers were observed to have a relatively higher cellulose content (as high as $80 \%$ for hemp) compared with plant biomass (a mere $63 \%$ for EFB) and forest products (48 \% for bamboo). With regard to cellulose and lignin, both plant biomass and bamboo have almost the same amount. It also was observed that almost all agro-fibers contain more cellulose than does wood.

Studies by Ashori [1] indicate that the dimensions of nonwood fibers are between those of hardwoods and softwoods. As shown in Table 1, the length of agro-fibers ranges from 0.50 to $600 \mathrm{~mm}$, whereas that of biomass fibers ranges from 0.66 to $250 \mathrm{~mm}$. According to Blackburn [62], fibers from fruits and seeds are few centimeters long, whereas fibers from stems and leaves are much longer, sometimes reaching more than $1 \mathrm{~m}$ long. Oil palm-based fibers are significantly shorter than fibers from other plant biomasses, bamboo, and hardwoods. Conversely, plant biomass fibers have a cell wall thickness similar to that of agro-fibers and some wood species. In many cases, bamboo has a thicker cell wall and longer fibers than any wood or nonwood. 
Table 1 Properties of nonwood fibers

\begin{tabular}{|c|c|c|c|c|c|c|c|}
\hline Materials & $\begin{array}{l}\text { Density }\left(\mathrm{g} / \mathrm{cm}^{3}\right) / \\
\text { specific gravity }\end{array}$ & Cellulose (\%) & Lignin (\%) & Length (mm) & Diameter $(\mu \mathrm{m})$ & $\begin{array}{l}\text { Cell wall } \\
\text { thickness }(\mu \mathrm{m})\end{array}$ & $\begin{array}{l}\text { Lumen } \\
\text { width }(\mu \mathrm{m})\end{array}$ \\
\hline Kenaf whole stem & $0.32-0.037[29]$ & $40.2-53.8[30,31]$ & $13-21[30,31]$ & $1.29[30]$ & $22.1[30]$ & $4.3[30]$ & $12.7[30]$ \\
\hline Kenaf core & $\begin{array}{l}0.1[10] \\
\quad 0.28-0.31[29]\end{array}$ & $47.4-49.0[31,32]$ & $19.2-19.4[31,32]$ & $\begin{array}{l}0.7-1.1 \\
\quad[30,31,33,34]\end{array}$ & $\begin{array}{l}21.4-38 \\
{[30,33,34]}\end{array}$ & $3.3-5.6[30,34]$ & $11-21[30,34]$ \\
\hline Kenaf bast & $1.3-1.5[35,36]$ & $55.0[31]$ & $14.7[31]$ & $\begin{array}{l}1.2-3.6 \\
{[30,31,34,37]}\end{array}$ & $\begin{array}{l}21.3-28.6 \\
{[30,34,37]}\end{array}$ & $6.2-6.9[34]$ & $8-16[30,34]$ \\
\hline Hemp & $1.48[36]$ & $80[38]$ & $4[38]$ & $22[38]$ & $20[38]$ & - & - \\
\hline Jute & $1.45[36]$ & $61-71[39]$ & $12[39]$ & $0.5-6.0[39]$ & $26-30[39]$ & & \\
\hline Flax & $1.54[36]$ & $60-70[39]$ & $2-3[39]$ & $6-65[15]$ & $20[15]$ & & \\
\hline Sisal & $0.76-1.45[35,36]$ & $70[15]$ & - & $180-600[40]$ & $100-300[41]$ & & \\
\hline Oil palm trunk & $0.27-0.44[42 \bullet]$ & $41.0[43 \bullet]$ & $24.5[43 \bullet]$ & $0.66[43 \bullet]$ & $16.6[43 \bullet]$ & $8.00[43 \bullet]$ & - \\
\hline Oil palm frond & - & $49.8-56.0[43 \cdot, 44]$ & $20.5[43 \bullet]$ & - & - & - & - \\
\hline Oil palm EFB & $0.18-1.32$ [45] & $50.5-62.9[43 \bullet, 46]$ & $17.8[43 \bullet]$ & $0.99[46]$ & $19.1[46]$ & $3.38[46]$ & - \\
\hline Bagasse & $0.52-1.47[46]$ & $55.75[47]$ & $20.5[47]$ & $1.59[47]$ & $21.0[47]$ & $5.6[47]$ & $9.7[47]$ \\
\hline Wheat straw & $0.02-1.10[48]$ & $43.2-49.8[49,50]$ & $19.6-21.2[49,50]$ & $1.14-1.18[49,50]$ & $\begin{array}{r}13.6-19.3 \\
{[49,50]}\end{array}$ & $\begin{array}{l}4.39 \\
3.96[49,50]\end{array}$ & $\begin{array}{l}5.7- \\
10.5[49,50]\end{array}$ \\
\hline Canola straw & $0.27-1.58[51]$ & $41.1[52]$ & $17.2[52]$ & $1.21[53]$ & $28[53]$ & $7.43[53]$ & $11.9[53]$ \\
\hline Coir & $1.15[54]$ & $44.2-33.2[40,44]$ & $32.8-20.5[40,44]$ & $50-250[40,55]$ & $270[55]$ & - & - \\
\hline Bamboo (5 years) & $0.58-0.95[56]$ & $46-48[57]$ & $22.9-23.0[57]$ & $2.0-2.4[57]$ & & & \\
\hline Outer & $0-81-0.84[56]$ & & & $1.70-2.03[56]$ & $18.5[56]$ & $7.03[56]$ & $5.44[56]$ \\
\hline Middle & $0.63-0.66[56]$ & & & $2.06-2.32[56]$ & $22.4[56]$ & $8.43[56]$ & $5.51[56]$ \\
\hline Inner & $0.58-0.59[56]$ & & & $1.86-2.39[56]$ & $19.6[56]$ & $6.80[56]$ & $5.96[56]$ \\
\hline Softwood & $0.35-0.61[58]$ & $30-60[59]$ & $21-37[59]$ & - & - & - & - \\
\hline Hardwood & $0.40-0.72[58]$ & $31-64[59]$ & $14-34[59]$ & - & - & - & - \\
\hline Hardwood (aspen) & - & - & - & $0.50-1.35[60]$ & $13-37[60]$ & $1.3-5.3[60]$ & - \\
\hline $\begin{array}{l}\text { Rubberwood } \\
\text { PB260-25 years }\end{array}$ & $0.60[61]$ & $44[61]$ & $23[61]$ & $1.34[61]$ & $27[61]$ & $6.0[61]$ & $14[61]$ \\
\hline
\end{tabular}

Specific gravity is presented in italic to differentiate the density and specific gravity

\section{Strength Properties}

Table 2 lists the mechanical properties of nonwood fibers. Most agro-fibers have greater tensile strength compared with plant biomass and bamboo, ranging from 80 to 1191,71 to 175 , and 441 to $800 \mathrm{MPa}$, respectively. According to Abdul Khalil et al. [31] and Horn and Setterholm [72], a high cellulose content as well as longer fibers and thicker cell walls may be responsible for the high strength of bamboo products. Most agro-fibers have a higher density, which explains the relatively higher mechanical strength of these fibers compared with wood. Kenaf, hemp, jute, and flax have higher tensile strength compared with EFB, bagasse, wheat straw, and coir. However, some agricultural crop fibers, such as jute, have a tensile strength of $370 \mathrm{MPa}$, slightly lower than that of bamboo [36, $65,71]$.

Nonwood fibers have large variations in properties compared with synthetic fibers. Using Young's modulus, Sobczak et al. [73] plotted the tensile strengths of both synthetic and natural fibers (Fig. 2). The values that they observed for natural fibers and wood varied from 7 to $70 \mathrm{GPa}[74,75]$. In comparison, values for synthetic fibers range from $70 \mathrm{GPa}$ (short glass fiber/long glass fiber) [76] to $240 \mathrm{GPa}$ (short carbon fiber) [77]. The vast differences found in natural fibers imply that these fibers are more heterogeneous than synthetic fibers. Such inconsistencies have been the biggest constraint on the commercialization of natural fiber-based products.

Bamboo strips were reported to have a modulus of rupture (MOR) ranging from 149.1 to $262.5 \mathrm{MPa}$ and a modulus of elasticity (MOE) comparable to that of softwood (Table 3). Different species and parts (node and internodes) of bamboo result in differences in MOR and MOE [78]; however, there is much less variation along the plant's height. [57]

\section{Bonding of Nonwood Fibers}

With regard to polymer matrix composites, there appears to be an optimum level of fiber-matrix adhesion that provides the best composite mechanical properties [83]. A strong fibermatrix bond is critical for superior mechanical properties in 


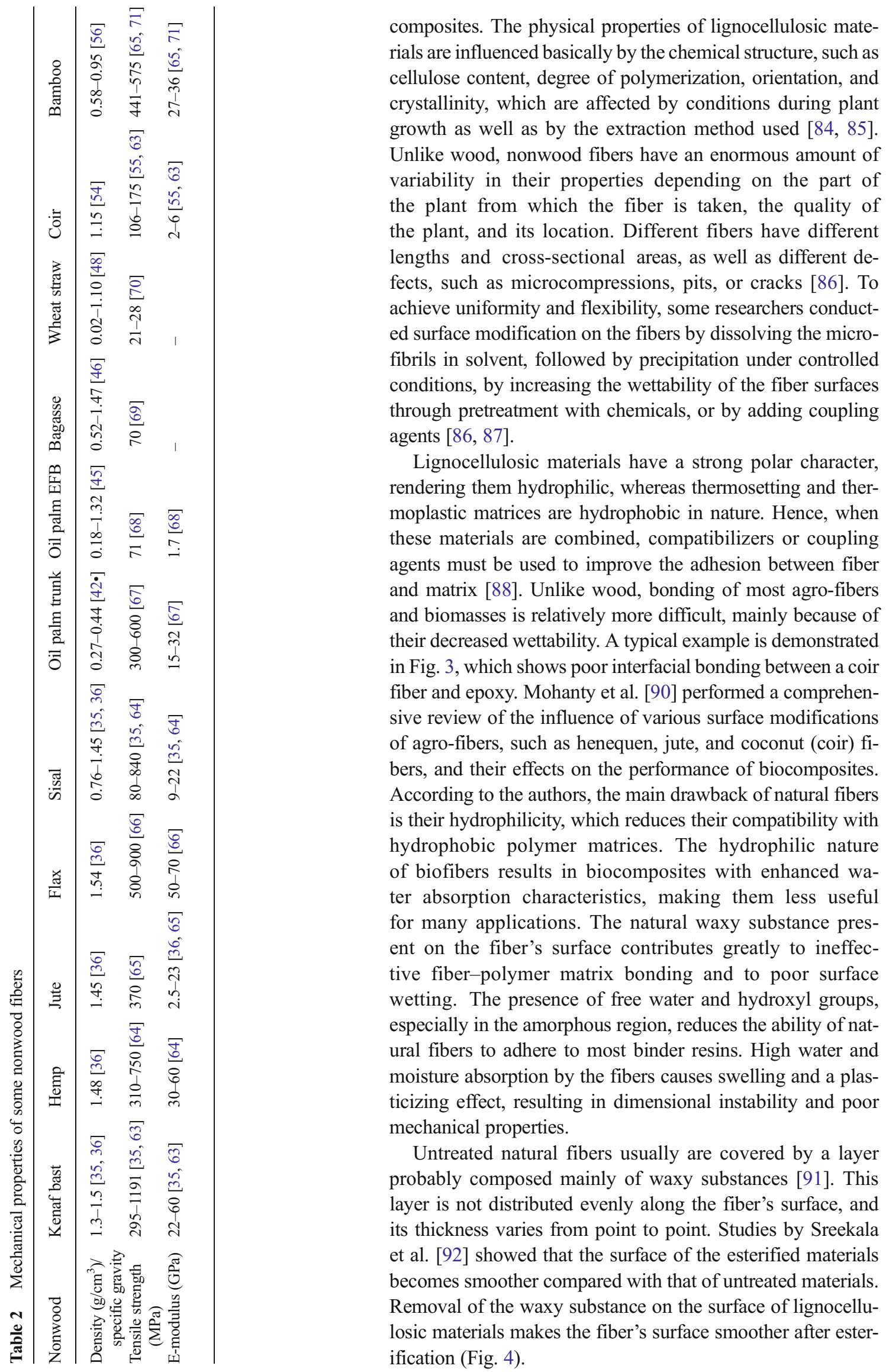


Fig. 2 Ashby plot presenting the absolute tensile strength vs. Young's modulus for various fiber types (source: after Sobczak et al. [73])

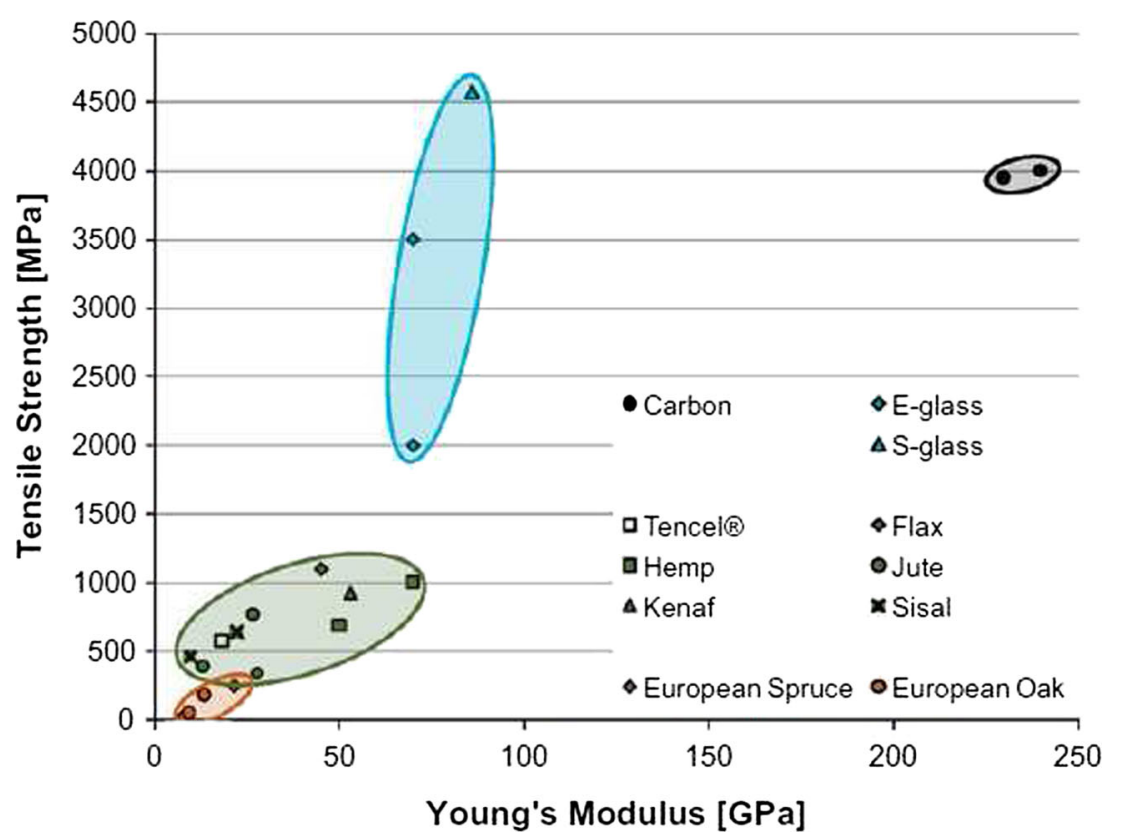

Our study on the pretreatment of oil palm EFB fibers showed tremendous improvement in fiber surfaces when treated with $\mathrm{NaOH}[94,95]$. Scanning electron microscope (SEM) images of untreated and treated fibers (Fig. 5a, b) clearly show fibrils that are aligned, forming a packed structure. The untreated fiber has a much rougher surface, with layers of impurities, suspected to be lignin and wax, covering the surface.

Table 3 Mechanical properties of some nonwoods

\begin{tabular}{|c|c|c|c|c|c|c|c|}
\hline \multirow[t]{3}{*}{ Materials } & \multirow[t]{3}{*}{ Density $\left(\mathrm{g} / \mathrm{cm}^{3}\right)$} & \multicolumn{2}{|c|}{ Static bending } & \multicolumn{4}{|c|}{ Compression strength } \\
\hline & & \multirow{2}{*}{$\begin{array}{l}\text { MOR } \\
(\mathrm{MPa})\end{array}$} & \multirow{2}{*}{$\begin{array}{l}\text { Young's } \\
\text { modulus (MPa) }\end{array}$} & \multicolumn{2}{|c|}{ Longitudinal || } & \multicolumn{2}{|l|}{ Tangential $\perp$} \\
\hline & & & & $\begin{array}{l}\text { Compressive } \\
\text { stress (MPa) }\end{array}$ & $\begin{array}{l}\text { Young's } \\
\text { modulus (MPa) }\end{array}$ & $\begin{array}{l}\text { Compressive } \\
\text { stress }(\mathrm{MPa})\end{array}$ & $\begin{array}{l}\text { Young's } \\
\text { modulus (MPa) }\end{array}$ \\
\hline \multicolumn{8}{|l|}{ Bamboo strip (5 years) [57] } \\
\hline Bottom & 0.75 & 186.2 & 13,162 & 93.6 & 4896 & 34.1 & 533 \\
\hline Middle & 0.78 & 184.8 & 13,410 & 86.6 & 4980 & 33.6 & 527 \\
\hline Top & 0.76 & 183.4 & 13,307 & 85.8 & 5185 & 35.3 & 552 \\
\hline \multicolumn{8}{|c|}{ Bamboo strip [78] (Schizostachyum brachycladum) } \\
\hline Node & 0.67 & 149.1 & 17,368 & - & - & - & - \\
\hline Internodes & 0.58 & 262.5 & 20,890 & & & & \\
\hline Rubberwood [79] (Hevea brasiliensis) & $0.46-0.65$ & 66 & 9240 & 32 & - & 5 & - \\
\hline$(12 \% \mathrm{MC})[80]$ & 0.58 & & & 39 & 4100 & & \\
\hline$(66 \% \mathrm{MC})[80]$ & - & & & 27 & 3500 & & \\
\hline \multicolumn{8}{|l|}{ 20-mm thickness } \\
\hline $\begin{array}{l}\text { Tropical hardwood Chengal [81] } \\
\text { (Neobalanocarpus heimii) }\end{array}$ & $0.92-0.98$ & 149 & 19,600 & 75.2 & - & 12 & - \\
\hline \multicolumn{8}{|l|}{ Softwood Pine [82] (Pinus radiata) } \\
\hline 4-mm thickness & 0.39 & - & 19,800 & - & - & - & - \\
\hline 8-mm thickness & 0.38 & & 14,800 & & & & \\
\hline
\end{tabular}

Italic indicates species name of the plants

|| parallel to the grain direction, $\perp$ perpendicular to the grain direction 

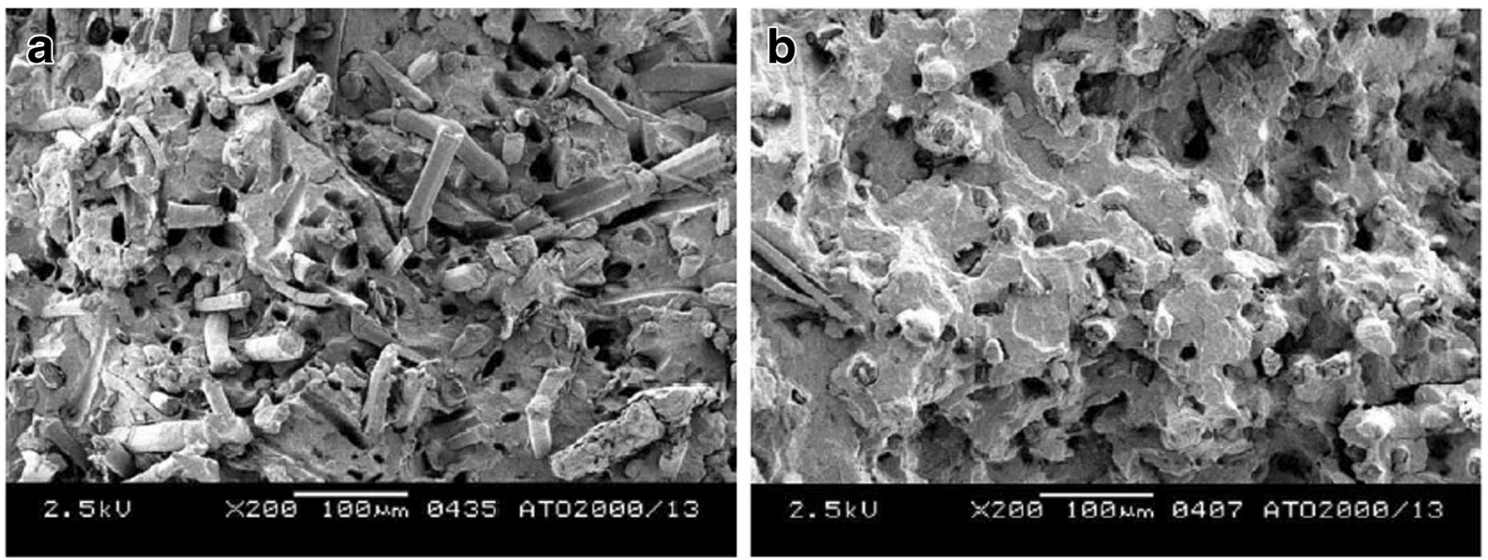

Fig. 3 SEM $\times 200$ of $30 \mathrm{wt} \%$ agro-fiber/PP composite. a Without a coupler. Voids and pull-outs are seen. b With a $3 \%$ Epolene G-3015 coupler. Good fiber wetting and interblocking are seen (source: Keener et al. [89])

\section{Wettability and Buffering Capacity}

Our research shows that wetting is necessary but not always sufficient for a strong bond and that contact angle detects changes in surfaces due to contamination or chemical modification $[29,95,96]$. Adhesion properties, such as wettability, $\mathrm{pH}$, and buffering capacity, of wood and nonwood are among the factors influencing the properties of most composite panels.

In conventional biocomposite manufacturing, thermosetting resins such as urea formaldehyde (UF), melamine urea formaldehyde (MUF), and phenol formaldehyde (PF) commonly are used as binders. These adhesives are sensitive to the $\mathrm{pH}$ of the substrate because the rate of cross-linking of most thermosetting adhesives is $\mathrm{pH}$ dependent [97]. Therefore, most adhesives are formulated to adapt to the acid range and buffer capacity of the substrate. The $\mathrm{pH}$ - and acidbuffering capacities of aqueous extracts from agro-fibers are reported to be significantly greater than those of softwoods, and in the presence of such materials, resin gel time increases greatly [98-100]. Paridah [6••] extensively studied both the wettability and buffering capacity of various nonwood fibers and concluded that both properties are crucial in determining the performance of the resulting composites. Figures 6, 7, 8, 9, 10,11 , and 12 show the results from studies on the wettability and buffering capacity of bamboo, kenaf, oil palm trunk (OPT), and straws.

\section{Properties of Composites from Nonwood Fibers}

Agricultural crops such as kenaf, jute, sisal, and flax, as well as biomass such as bagasse, oil palm fibers, and wheat and rice straws, have great potential in composite manufacturing. The use of these materials in the production of composite panels and paper products now is considered attractive both from an economical (or economic) and environmental point of view. Use of these fiber resources helps protect virgin forests in regions where there is a shortage of wood [103]. In addition,
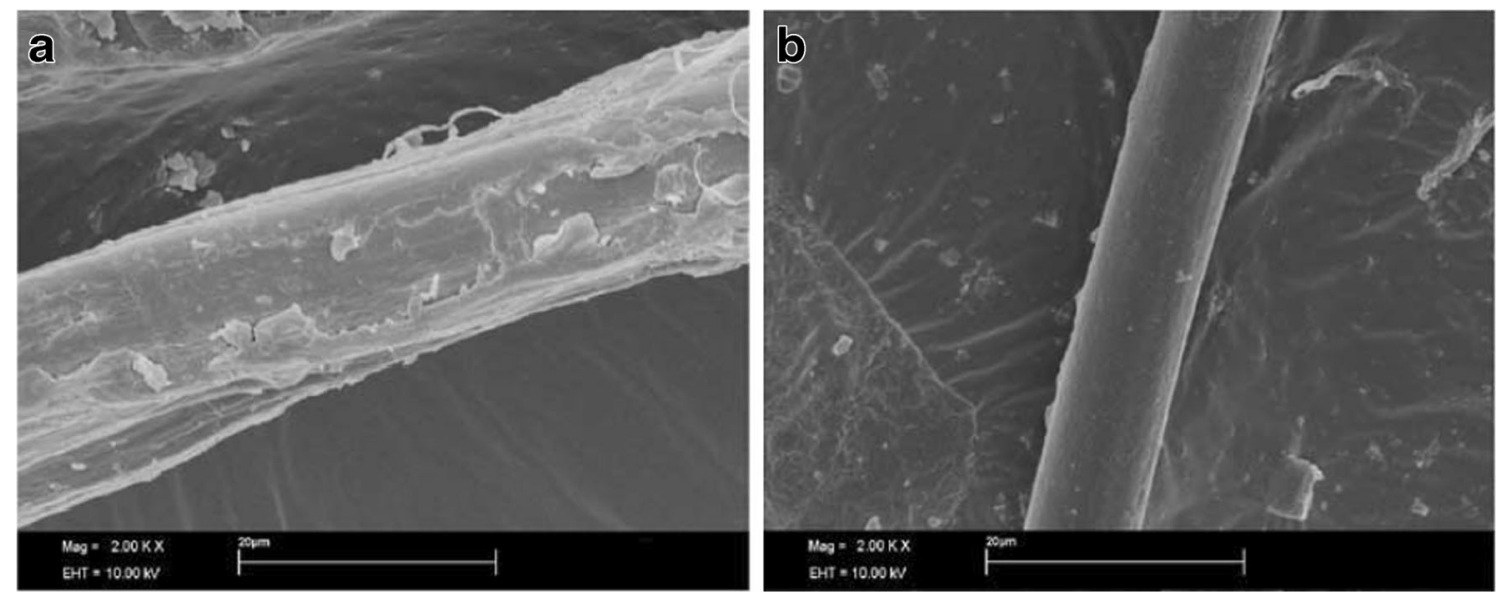

Fig. 4 SEM images of untreated and esterified hemp fiber: a untreated and $\mathbf{b}$ acetylated (source: Tserki et al. [93]) 

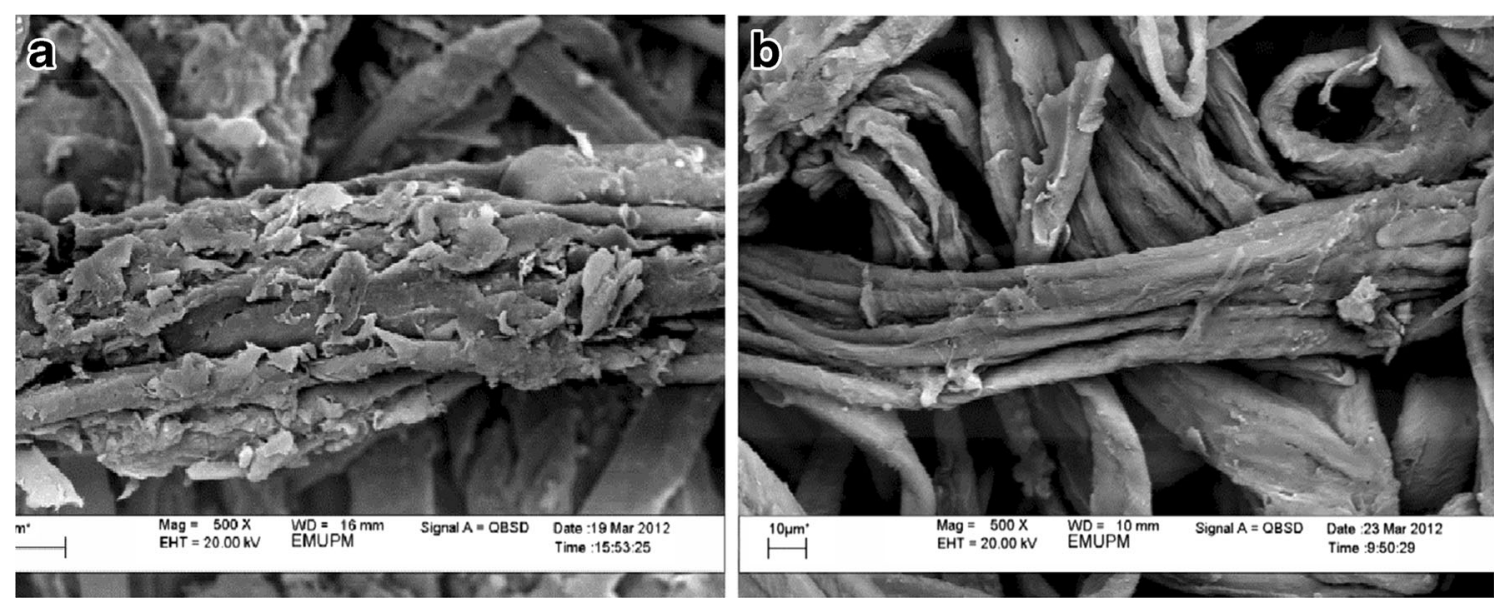

Fig. 5 SEM image of an EFB fiber a untreated and $\mathbf{b}$ after soaking in $\mathrm{NaOH}(\times 500$ magnification) (source: Norul Izani et al. [94])

large quantities of biomass are available today in many parts of the world where open burning is prohibited [19].

Efforts to convert nonwood fibers into quality products have intensified during the past 20 years because they are inexpensive, have low density, are tough, cause less dermal and respiratory irritation, are easy to separate, and are biodegradable [3•]. Wood-based industries are the most appealing sector for these efforts because nonwoods closely resemble wood fibers and therefore have similar applications in the furniture and construction industries. The following sections review the mechanical and physical properties of some of these products, specifically those of MDF, particleboard, plywood, laminated veneer lumber (LVL), and glued laminated panels.

\section{Fiberboard}

The mechanical and physical properties of MDF made from nonwood are similar to those of wood. Table 4 shows the properties of MDF made from different fiber sources. The mechanical properties of agro-fibers and plant biomass are similar; however, in some cases, superior fibers do not necessarily result in superior board. Kenaf bast, for instance, has high density, long slender fibers, and superior tensile strength compared with other natural fibers; however, when it is converted into MDF, the properties of the resulting board are very poor [33, 37]. Kenaf core, on the other hand, has short fibers, a thin cell wall, and a very large lumen size but produces MDF with much greater MOR, MOE, and internal bonding (IB) as well as greater dimensional stability compared with kenaf bast. Paridah $[6 \cdot \bullet$ attributed the poor performance of kenaf bast fibers to their low wettability, which limits adhesive penetration and consequently reduces bond integrity. She also concluded that the low fiber density $\left(0.1 \mathrm{~g} / \mathrm{cm}^{3}\right)$, thin cell wall, and large lumen of kenaf core fibers provide better compaction and densification of fibers, which result in the superior performance of kenaf board.

Likewise, the performance of MDF made from biomass with shorter fibers, such as OPT, bagasse, and wheat straw a

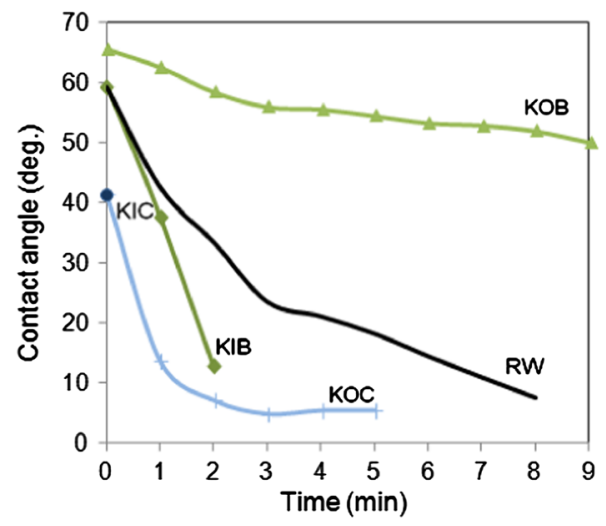

b

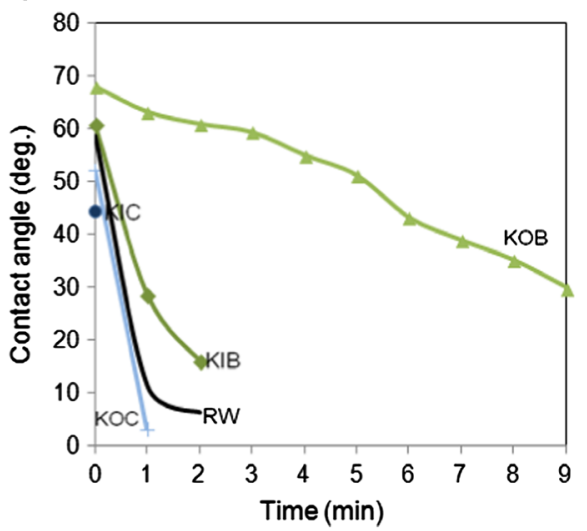

- Kenaf's' outer core (KOC)

$\rightarrow$ Kenaf's' inner core (KIC)

- Kenaf's' outer bast (KOB)

- Kenaf's' inner bast (KIB)

- Rubberwood (RW)

Fig. 6 Contact angles of kenaf using a $0.1 \mathrm{~N} \mathrm{HCl}$ and $\mathbf{b} 0.1 \mathrm{~N} \mathrm{NaOH}$ solutions on different substrates as a function of time (source: Juliana et al. [29]) 

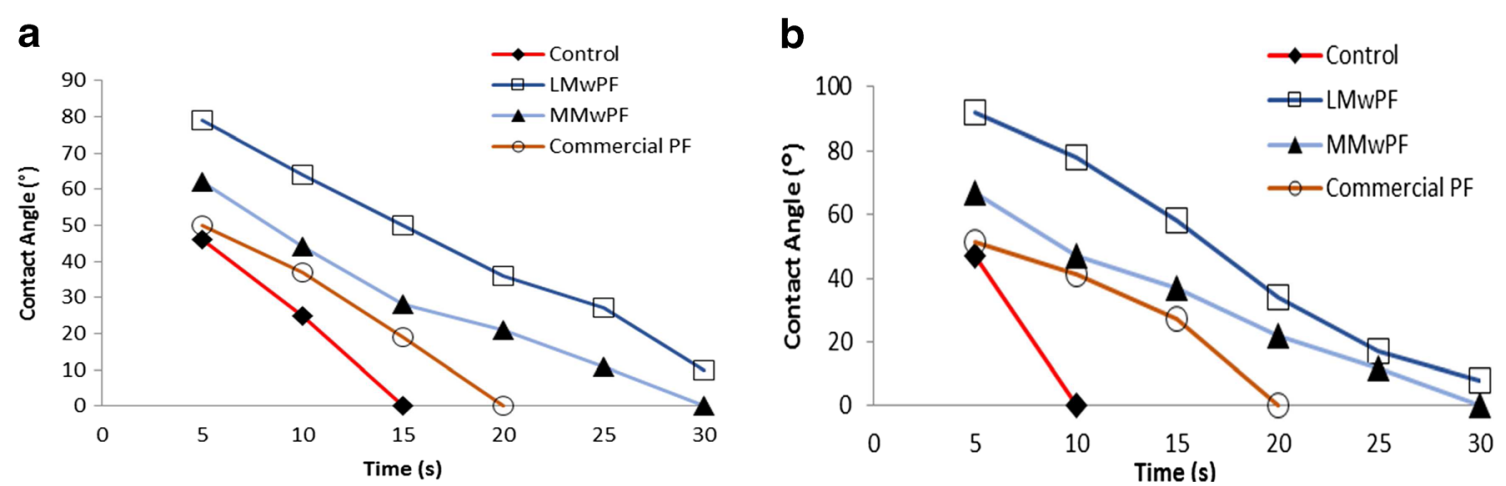

Fig. 7 Contact angle of distilled water on $\mathbf{a}$ outer and $\mathbf{b}$ inner sections of OPT veneer as a function of time (source: Nor Hafizah et al. [101])

(0.66, 1.59 , and $1.18 \mathrm{~mm}$, respectively), is comparable to that of boards made from agro-fibers. A similar result has been observed in bamboo. Although bamboo has excellent fiber properties compared with other nonwood fibers, when it is converted into MDF, the results are reversed. Because the amount of resin used in bamboo is low, increasing the amount of resin might improve the board's performance significantly. Zaidon et al. [109] reported similar results in using bamboo for hardboard. Their results revealed that optimum-quality mechanical bamboo pulps for hardboard production may be obtained by pretreating the chips by soaking them in $2 \% \mathrm{NaOH}$ for $6 \mathrm{~h}$ and then refining them in two cycles (first with $2.5-\mathrm{mm}$ and second with $0.5-\mathrm{mm}$ plate gaps). Apparently, MDFs made from bagasse and wheat

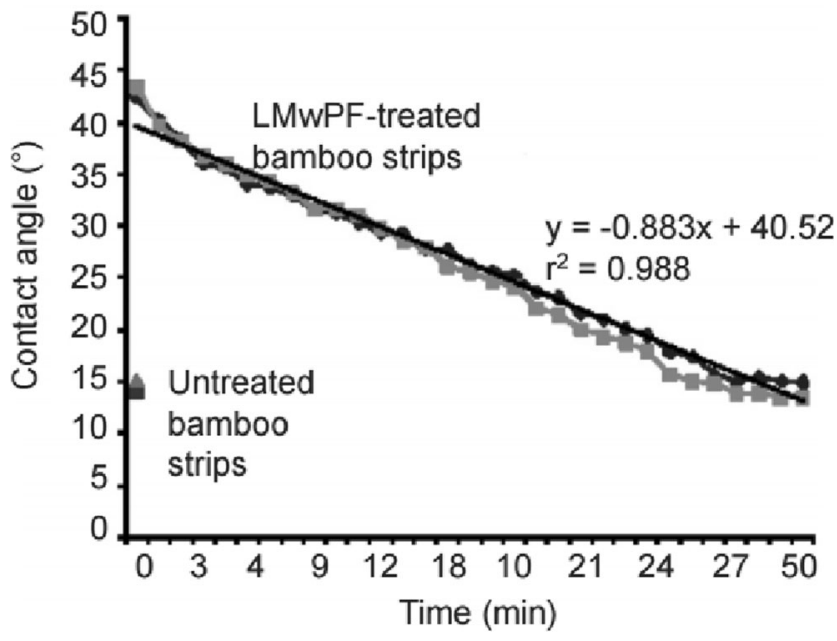

$\leftarrow$ - Inner surface (treated) $\quad=-$ Outer surface (treated) - Inner surface (untreated) ^ Outer surface (untreated)

Fig. 8 Contact angle vs. time ( $\mathrm{min})$ of phenolic-treated and untreated bamboo strips (source: Anwar et al. [96]). Low molecular weight phenol formaldehyde (LMwPF) straw also require a higher resin content to achieve superior board properties.

\section{Particleboard}

Table 5 lists the mechanical and physical properties of particleboard made from various types of fibers. Generally, particleboard made from nonwood material has relatively poorer properties than that made from rubberwood, the main wood species used in particleboard and MDF plants in Southeast Asia. The best nonwood particleboards are made from hemp, OPT, bagasse, and canola straw. As with MDF, particleboard made from kenaf bast has significantly lower MOR and MOE values than panels made from kenaf core alone. Interestingly, the strength increases markedly when whole kenaf stem is used.

It has been observed that OPT board tends to have greater thickness swelling and water absorption than boards from other nonwoods, including EFBs and oil palm fronds. This condition may be a result of the parenchyma tissues in the trunk, which behave like a sponge and tend to absorb water easily. The parenchyma also has some advantages with regard to IB. Hashim et al. [114] produced much stronger particleboard from OPT without using a synthetic binder. In this case, they used a higher temperature and a longer pressing time to plasticize both the lignin and sugars (in the parenchyma tissues) to create natural binders, resulting in high MOR and IB strengths.

Most bast and straw fibers have low bonding strength due to the waxy cuticle layer on the outside of the fibers, which is responsible for their low wettability. According to Freytag and Donze [120], a small amount of residual wax may form a thin film on the fiber surface when heated above $60-70{ }^{\circ} \mathrm{C}$, thus obstructing the penetration of aqueous solutions. This in turn leads to low resin penetration into the cell walls and lumens, reducing the number of links formed between the cells and the 
a

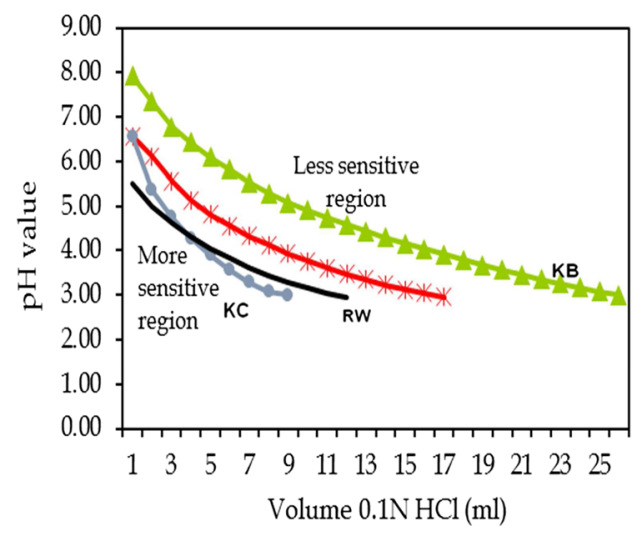

b

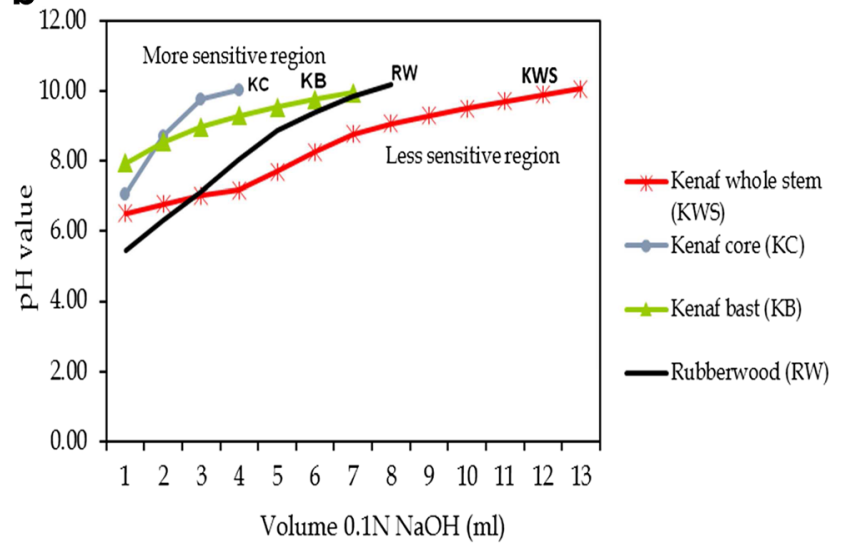

Fig. 9 Comparative stability of different parts of kenaf stem and rubberwood in a acidic and b alkaline solutions (source: Juliana et al. [29])

adhesive. These effects are more prominent in particleboards than in MDF; in the latter, most of the waxy layer is dissolved during the pulping process.

\section{Veneer-Based and Laminated Products}

Studies on plywood and laminated panels using bamboo and OPT were reported by Anwar et al. [121], Sulastiningsih et al. [122], Loh et al. [42•], Rahman et al. [123], and Srivaro et al. [124]. As shown in Table 6, both plywood and laminated products from OPT and bamboo have much higher strength and stiffness compared with particleboard and MDF. Laminated bamboo board exhibits much better performance than any of the fiber types, including wood products.

In plywood manufacturing, fiber properties (density and fiber length) play an important role in producing a highquality product [128]. A previous study by Bhat et al. [129] revealed that bamboo has high elasticity and strength, making it suitable for the construction industry. For instance, bamboo, with high density $\left(0.8-1.4 \mathrm{~g} / \mathrm{cm}^{3}\right)$ compared with OPT $(0.27-$ $0.44 \mathrm{~g} / \mathrm{cm}^{3}$ ), has MOR, MOE, and shear values quite similar to those of commercial tropical hardwood plywood [42•, 121]. According to Loh et al. [42•], OPT has two regions within the trunk's diameter: an outer and an inner section. The outer section represents a much denser and stronger material compared with the inner section. As seen in Table 6, plywood made from only the inner part of OPT is inferior, even with an increased adhesive spread rate. Because of this variation in density, OPT veneers must be segregated into density classes to improve the strength and bond integrity of OPT plywood [42•]. In this study, arranging the low-density veneer in the core significantly increased the MOR and MOE values.

As shown in Table 6, laminated boards from bamboo are superior to those made from wood and OPT. A unidirectional laminated bamboo (ULB) board has higher strength, stiffness, and shear than a cross-laminated bamboo (CLB) board. [126] Notably, OPT performs quite well
Fig. 10 Buffering capacity of wheat straw toward acid (source: Halvarsson et al. [102])

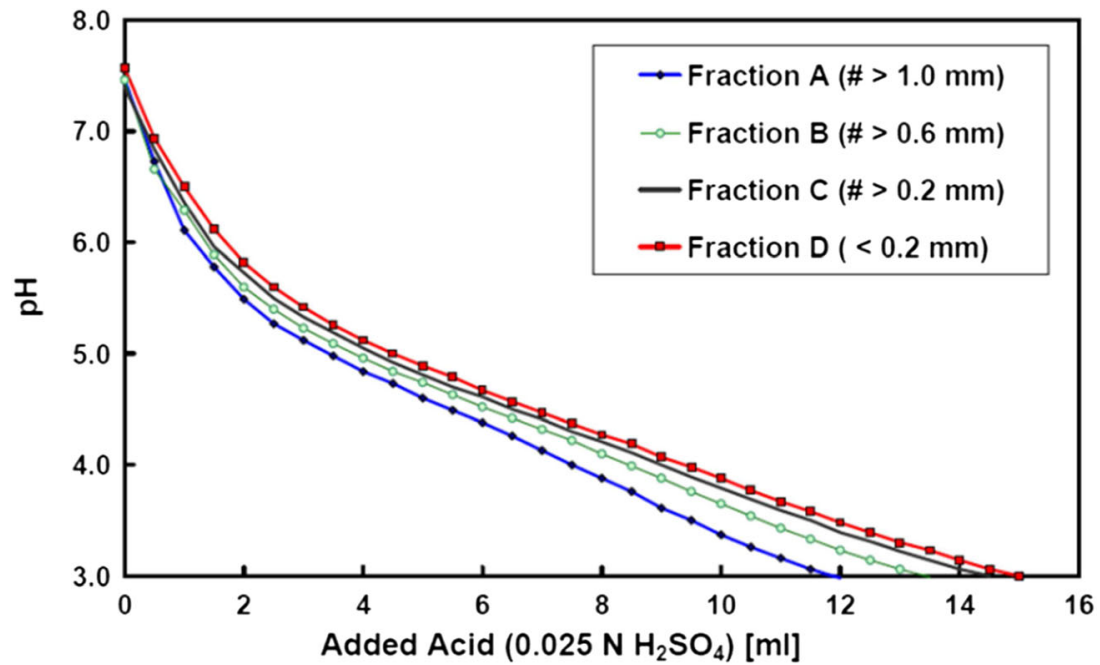



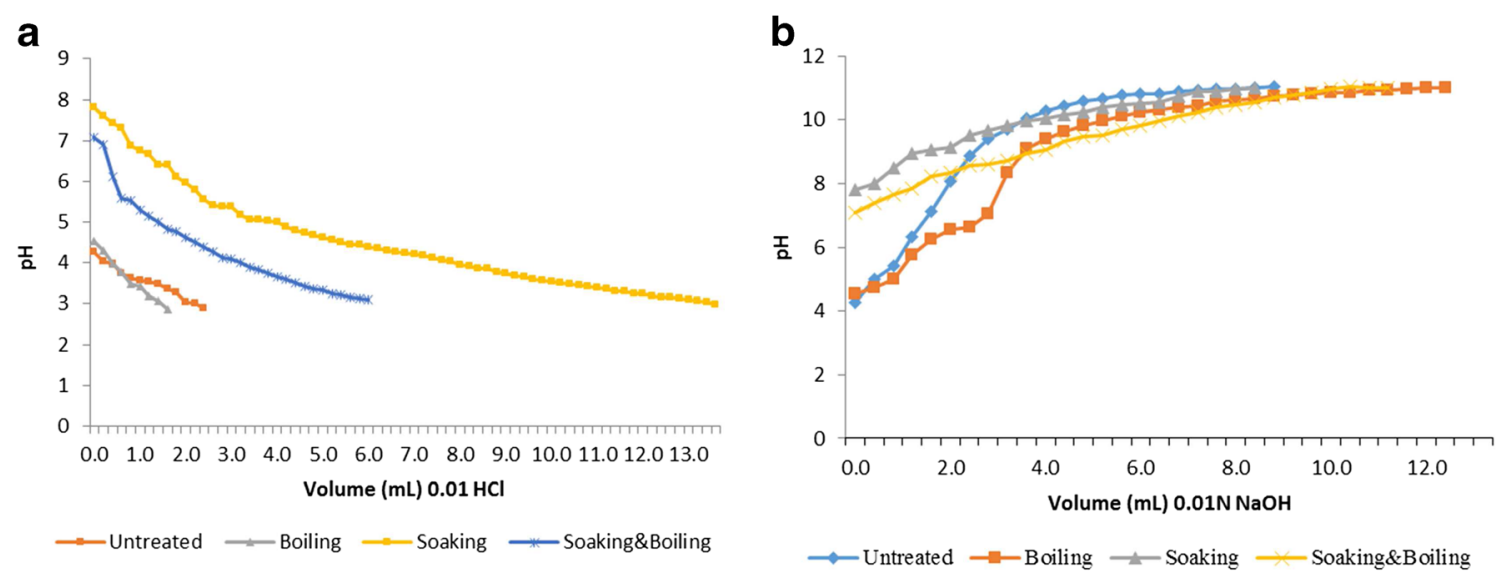

Fig. 11 Comparative stability of different EFB fiber treatments under a acidic and $\mathbf{b}$ alkaline solutions (source: Norul Izani et al. [94])

compared with other light wood species; thus, it may be of future importance because it is available throughout the year as plant biomass.

\section{Issues and Challenges}

Generally, most nonwood fiber composites have three issues that must be addressed: a consistent supply, adhesion, and dimensional stability. A sustainable and consistent supply of raw materials remains the most crucial factor in determining the survival of the nonwood composite industry. In the AsiaPacific region, only a few commercial plants are seriously looking at using nonwood as a raw fiber material, despite the large number of studies being conducted. As for the issues of adhesion and dimensional stability, some commercial sectors have come up with several innovative solutions, including the use of new additives, nanoparticles for increasing dimensional stability, and high-quality preparation methods to enable more reproducible properties and better processing control. An increased understanding of the influence of factors

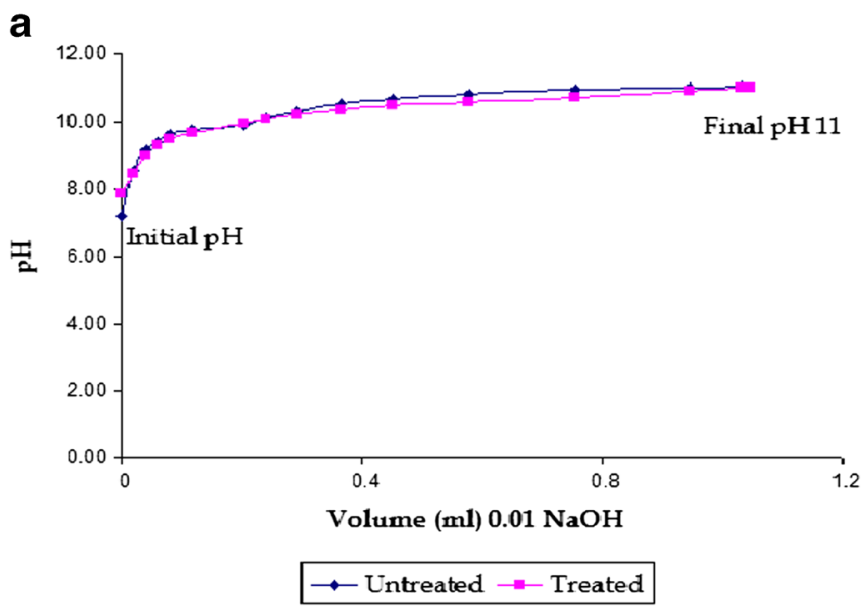

such as moisture, fiber type, and fiber content has improved the mechanical properties of composites as well as the quality of their end products.

Surface interaction between resin polymer and natural fibers is an area that requires more concerted efforts. Because nonwood fibers come from many different sources, they vary greatly; therefore, there is a need to characterize their properties, particularly the interface between fiber and matrix, to obtain crucial information on adhesion strength as well as the resulting product. This evaluation may be done through several techniques, such as the following:

- Micromechanical techniques

- Single-fiber pull-out test

- Fiber bundle pull-out test

- Single-fiber fragmentation test

- Microbond test

- Spectroscopic techniques

b

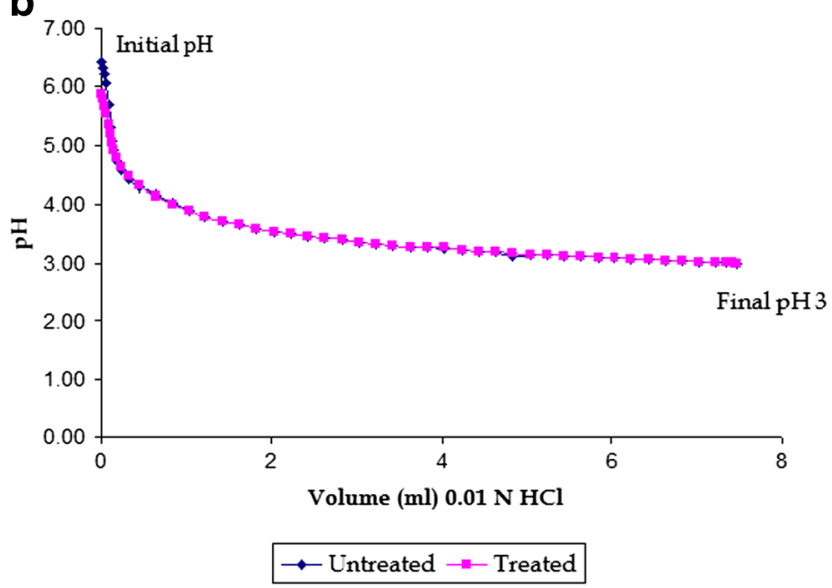

Fig. 12 Buffering capacity of bamboo strips in a acidic and $\mathbf{b}$ alkaline solutions (source: Anwar et al. [96]) 


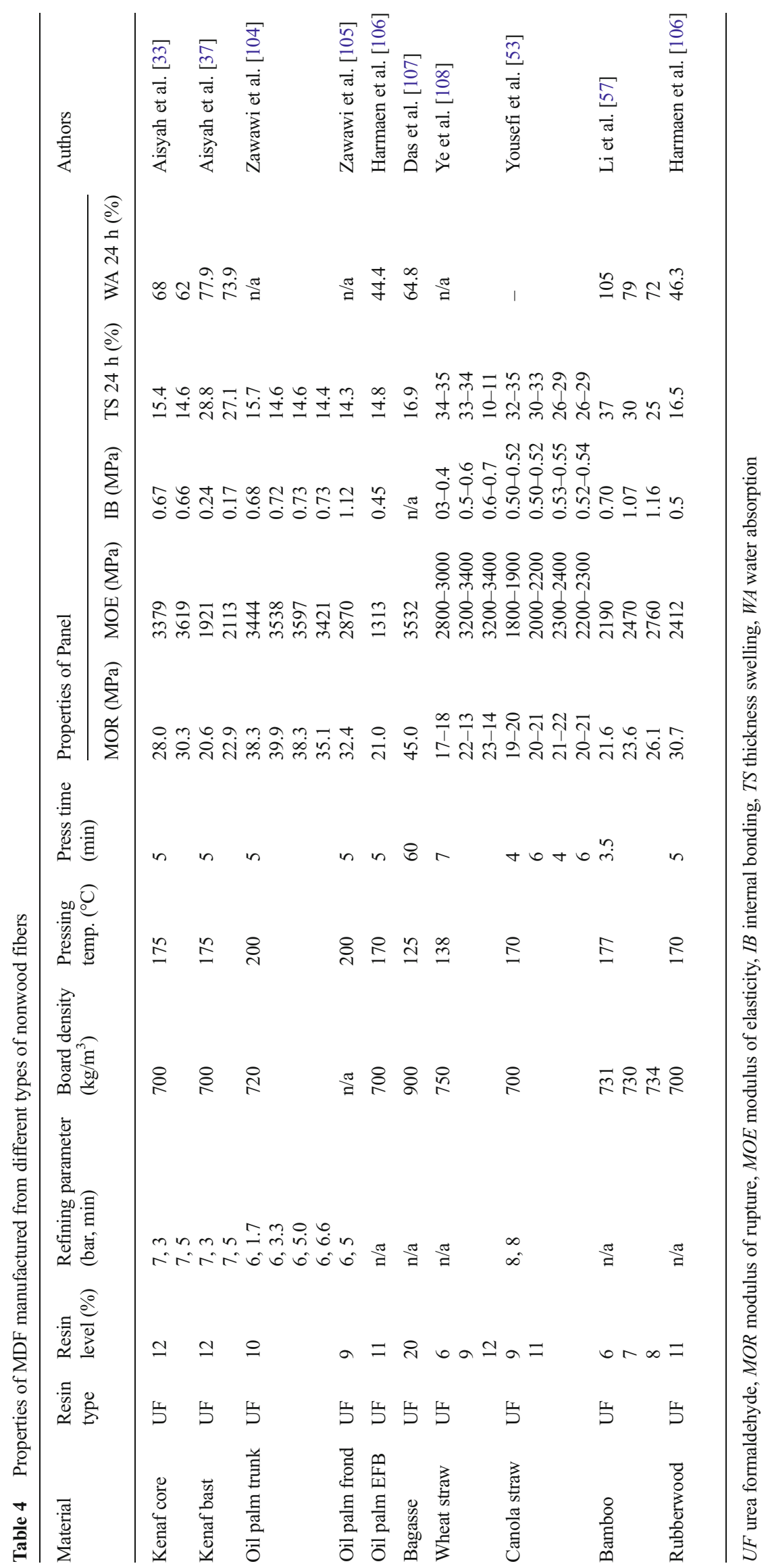


Table 5 Properties of particleboard manufactured from different types of nonwood fibers

\begin{tabular}{|c|c|c|c|c|c|c|c|c|c|c|c|}
\hline \multirow[t]{2}{*}{ Material } & \multirow{2}{*}{$\begin{array}{l}\text { Resin } \\
\text { type }\end{array}$} & \multirow{2}{*}{$\begin{array}{l}\text { Resin } \\
\text { level (\%) }\end{array}$} & \multirow{2}{*}{$\begin{array}{l}\text { Board } \\
\text { density } \\
\left(\mathrm{kg} / \mathrm{m}^{3}\right)\end{array}$} & \multirow{2}{*}{$\begin{array}{l}\text { Pressing } \\
\text { temp. } \\
\left({ }^{\circ} \mathrm{C}\right)\end{array}$} & \multirow{2}{*}{$\begin{array}{l}\text { Press } \\
\text { time } \\
(\mathrm{min})\end{array}$} & \multicolumn{5}{|c|}{ Properties of panel } & \multirow[t]{2}{*}{ Authors } \\
\hline & & & & & & $\begin{array}{l}\text { MOR } \\
(\mathrm{MPa})\end{array}$ & $\begin{array}{l}\mathrm{MOE} \\
(\mathrm{MPa})\end{array}$ & $\begin{array}{l}\mathrm{IB} \\
(\mathrm{MPa})\end{array}$ & $\begin{array}{l}\text { TS } 24 \mathrm{~h} \\
(\%)\end{array}$ & $\begin{array}{l}\text { WA } 24 \mathrm{~h} \\
(\%)\end{array}$ & \\
\hline Kenaf stem & UF & $\begin{array}{l}10-\mathrm{F} \\
8-\mathrm{M}\end{array}$ & 700 & $\begin{array}{l}150 \\
130 \\
150 \\
130 \\
150\end{array}$ & $\begin{array}{l}5 \\
5 \\
5 \\
5 \\
7 \\
7 \\
5 \\
7 \\
5 \\
7\end{array}$ & $\begin{array}{l}13.90 \\
12.80 \\
12.70 \\
13.30 \\
15.40 \\
13.00 \\
13.40 \\
13.50 \\
15.20 \\
16.30\end{array}$ & $\mathrm{n} / \mathrm{a}$ & $\begin{array}{l}0.40 \\
0.37 \\
0.36 \\
0.38 \\
0.410 .37 \\
0.39 \\
0.40 \\
0.43 \\
0.43\end{array}$ & $\begin{array}{l}19.1 \\
12.3 \\
14.5 \\
12.7 \\
18.2 \\
16.6 \\
17.8 \\
14.2 \\
10.2 \\
10.2\end{array}$ & $\mathrm{n} / \mathrm{a}$ & $\begin{array}{l}\text { Kalaycioglu and } \\
\text { Nemli [110] }\end{array}$ \\
\hline $\begin{array}{l}\text { Kenaf stem } \\
\text { Kenaf core } \\
\text { Kenaf bast }\end{array}$ & UF & 10 & 700 & 160 & 6 & $\begin{array}{l}15.1 \\
11.5 \\
2.3\end{array}$ & $\begin{array}{l}1559 \\
1365 \\
400\end{array}$ & $\begin{array}{l}0.51 \\
0.09 \\
0.02\end{array}$ & $\begin{array}{l}28 \\
67 \\
68\end{array}$ & $\begin{array}{l}77 \\
179 \\
197\end{array}$ & Juliana et al. [111] \\
\hline Hemp & UF & $\begin{array}{l}10-\mathrm{F} \\
8-\mathrm{M}\end{array}$ & 700 & 200 & $\mathrm{n} / \mathrm{a}$ & $16-17$ & $3400-3500$ & $0.77-0.79$ & $27-29$ & $74-79$ & Nikvash et al. [112] \\
\hline Flax & UF & 13 & 750 & 200 & 6 & 11.72 & $\mathrm{n} / \mathrm{a}$ & 0.09 & 62.9 & $\mathrm{n} / \mathrm{a}$ & $\begin{array}{l}\text { Papadopoulos and } \\
\text { Hague [113] }\end{array}$ \\
\hline $\begin{array}{l}\text { OPT (strand) } \\
\text { OPT (Fine) }\end{array}$ & No resin & $\mathrm{n} / \mathrm{a}$ & 800 & 180 & 20 & $\begin{array}{l}24.95 \\
4.04\end{array}$ & $\mathrm{n} / \mathrm{a}$ & $\begin{array}{l}0.93 \\
0.49\end{array}$ & $\begin{array}{l}41.6 \\
43.6\end{array}$ & $\begin{array}{l}80-85 \\
104-109\end{array}$ & Hashim et al. [114] \\
\hline Oil palm frond & UF & $\begin{array}{l}8 \\
10 \\
12\end{array}$ & 700 & 160 & 6 & $\begin{array}{l}10.83 \\
6.89 \\
12.03\end{array}$ & $\begin{array}{l}890 \\
639 \\
1049\end{array}$ & $\begin{array}{l}0.57 \\
0.56 \\
0.62\end{array}$ & $\begin{array}{l}23 \\
28 \\
19\end{array}$ & $\begin{array}{l}92 \\
99 \\
83\end{array}$ & Saiful Azry et al. [115] \\
\hline Oil palm EFB & MUF & 11 & 650 & 160 & 6 & 21.99 & 1276 & 0.80 & 11.3 & 75 & Zaidon et al. [116] \\
\hline Bagasse & UF & $\begin{array}{l}10-\mathrm{F} \\
8-\mathrm{M}\end{array}$ & 700 & 200 & $\mathrm{n} / \mathrm{a}$ & $17-18$ & $3100-3200$ & $0.42-0.44$ & $25-27$ & $61-66$ & Nikvash et al. [112] \\
\hline Wheat straw & UF & $5-17$ & 700 & 200 & 2 & 3.0 & 660 & 0.02 & 240 & $\mathrm{n} / \mathrm{a}$ & Boquillon et al. [117] \\
\hline Canola straw & UF & $\begin{array}{l}10-\mathrm{F} \\
8-\mathrm{M}\end{array}$ & 700 & 200 & $\mathrm{n} / \mathrm{a}$ & $12-13$ & $3100-3200$ & $0.12-0.14$ & $82-84$ & $110-115$ & Nikvash et al. [112] \\
\hline Rice husk & UF & 8 & 650 & 180 & 8 & 4.69 & 176 & 0.04 & 49 & 67 & Melo et al. [118] \\
\hline Sunflower stalk & UF & $\begin{array}{l}11-\mathrm{F} \\
9-\mathrm{M}\end{array}$ & 700 & 150 & 7 & 15.65 & 1800.2 & 0.46 & 25.05 & 82.22 & Bektas et al. [119] \\
\hline Bamboo & UF & 8 & 650 & 180 & 8 & 11.25 & 1343 & 0.22 & 30 & 72 & Melo et al. [118] \\
\hline Rubberwood & UF & 10 & 700 & 160 & 6 & 19.6 & 2712 & 1.52 & 33 & 70 & Juliana et al. [111] \\
\hline
\end{tabular}

$O P T$ oil palm trunk, $U F$ urea formaldehyde, $M U F$ melamine urea formaldehyde, $M O R$ modulus of rupture, $M O E$ modulus of elasticity, $I B$ internal bonding, $T S$ thickness swelling, $W A$ water absorption, $F$ face, $M$ middle, $n / a$ not available

- Surface characterization of the fiber (before and after treatment)

- Microscopic techniques

- SEM

- Optical microscopy

- Stereomicroscopy

- Contact angle measurement

- Wettability

- Surface energy

\section{Future Directions}

Large amounts of nonwoods are readily available in the form of plantation crops, biomass, and forest products.
These fiber resources differ significantly from one another; thus, specific harvesting and collection systems are needed to ensure a consistent supply of each raw material. Once such systems are established, there is no limit to the use of these fibers as raw materials in manufacturing particleboard, MDF, plywood, and laminated board. Kenaf core, OPT, bagasse, and straws (from wheat, rice, and oats) have promising properties for MDF production, whereas hemp, bagasse, OPT, and canola straw are more suitable for particleboard manufacture. In laminated products, the mechanical and physical properties of bamboo are far superior to those of panels made from wood species. OPT may be an important fiber resource in the future because of its sustainability and availability. All these new fiber resources demonstrate certain advantages over conventional composites, with some having greater mechanical properties. 


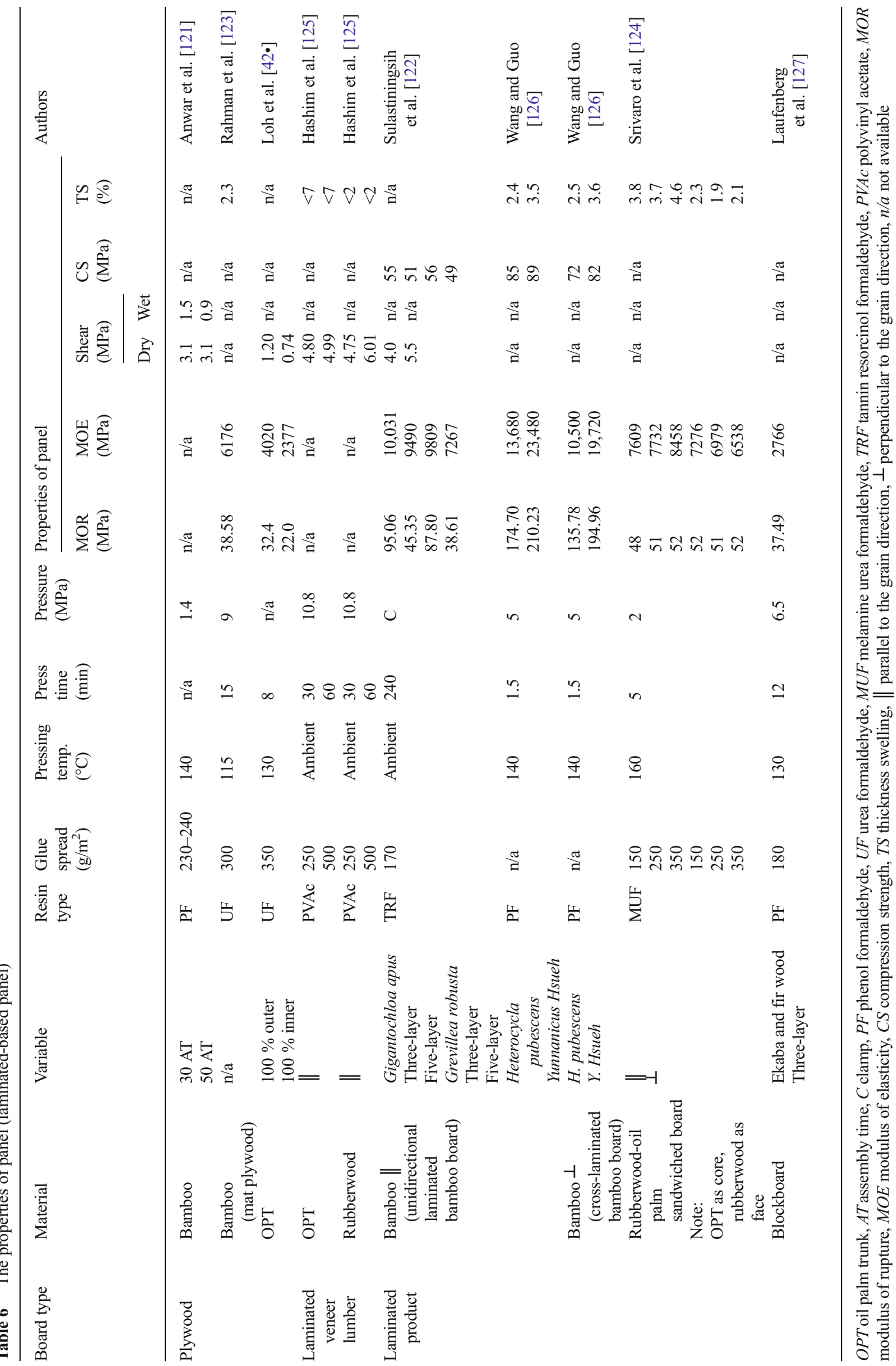




\section{Compliance with Ethics Guidelines}

Conflict of Interest The authors of this paper declare that they have no conflicts of interest

Human and Animal Rights and Informed Consent This article contains no studies with human or animal subjects performed by the author.

\section{References}

Papers of particular interest, published recently, have been highlighted as:

- Of importance

•. Of major importance

1. Ashori A. Nonwood fibres - a potential source of raw material in papermaking. Polym-Plast Technol Eng. 2006;45:1133-6.

2. Sen T, Reddy HNJ. Various industrial applications of hemp, kenaf, flax and ramie natural fibres. Int J Innov Manag Technol. 2011;2(3):192-8.

3. Mohanty AK, Misra M, Drzal LT. Sustainable bio-composites from renewable resources: opportunities and challenges in the green materials world. J Polym Environ. 2002;10(1-2):19-26. This article highlights the importance of natural fibers in biocomposite applications, as well as in comparison with synthetic fibers.

4. Ho MP, Wang H, Lee JH, Ho CK, Lau KT, Leng J, et al. Critical factors on manufacturing processes of natural fibre composites. Compos Part B. 2012;43:3549-62.

5. Smole MS, Hribernik S, Kleinschek KS, Kreže T. Chapter 15: plant fibres for textile and technical applications. Adv Agrophy Res. 2013;1:52372.

6.• Paridah MT. Bonding with natural fibres. Inaugural Lecture. Universiti Putra Malaysia. Serdang: UPM Press; 2013. This author conducted extensive studies on both the wettability and buffering capacity of various nonwood fibers and concluded that both properties are crucial in determining the performance of the resulting composites.

7. Varmolla MI, Carle JB. The importance of hardwoods plantation in the tropics and subtropics. Int For Rev. 2002;4(2):1-20.

8. Pande H, Roy DN. Delignification kinetics of soda pulping of kenaf. J Wood Chem Technol. 1996;16(3):311-25.

9. FAO: Food and Agriculture Organization of the United Nations. Common fund for commodities, pp 117. 20 October 2008; Rome. In Proceedings of the Symposium on Natural Fibres. Technical Paper No. 56. 2008.

10. Paridah MT, Ahmed AB, Saiful Azry SOA, Ahmed Z. Retting process of some bast plant fibres and its effect on fibre quality: a review. Bioresources. 2011;6(4):5260-81.

11. Liu A. Making pulp and paper from kenaf, 2004. http://www. chinaconsultinginc.com. Accessed 13 Feb 2015.

12. FAO: Food and Agriculture Organization of the United Nations. Future fibres, 2015, http://www.fao.org/economic/futurefibres/ fibres/coir/en/. Accessed 2 March 2015.

13. Yusoff S. Renewable energy from palm oil-innovation on effective utilization of waste. J Clean Prod. 2006;14(1):87-93.

14. Ng WPQ, Lam HL, Ng FY, Mustafa K, Lim JHE. Waste-towealth: green potential from palm biomass in Malaysia. J Clean Prod. 2012;34:57-65.

15. KeTTHA: Kementerian Tenaga, Teknologi Hijau dan Air. Green impact: low carbon green growth. Ministry of Energy, Green Technology and Water, Putrajaya, Malaysia, 2011.
16. Soeminta DS. Roundtable on sustainable palm oil public summary report. RSPO Certification Assessment Report: Adela Palm Oil Mill \& Lok Heng Palm Oil Mill, FELDA, 2009. http://www.tuv. $\mathrm{com} / \mathrm{media} /$ indonesia/brochure_2/forest_certification/rspo public announcement/Felda_RSPO_Public_Summary_Report 02052012.pdf. Accessed 27 May 2015.

17. UNEP: United Nations Environment Programme. Converting waste oil palm trees into a resource, 2012. http://www.unep.org/ietc, assessed on 28 May 2015.

18. Rasul MG, Rudolph V, Carsky M. Physical properties of bagasse. Fuel. 1999;78:905-10.

19. Mantanis G, Nakos P, Berns J, Rigal L. Turning agricultural straw residues into value-added composite products: a new environmentally friendly technology, pp 840-848. In Proceedings of the 5th International Conference on Environmental Pollution. 2000.

20. FAO: Food and Agriculture Organization of the United Nations. Statistics division, 2015 $5^{\mathrm{b}}$. http://faostat3.fao.org/download/Q/QC/E. Accessed 11 March 2015.

21. Ramamoorthy SK, Skrifvars M, Persson A. A review of natural fibers used in biocomposites: plant, animal and regenerated cellulose fibers. Polym Rev. 2015;55(1):107-62.

22. Mahdavi M, Clouston PL, Arwade SR. Development of laminated bamboo lumber: review of processing, performance, and economical considerations. J Mater Civil Eng. 2011;23(7):1036-42.

23. Zhang QS, Jiang SX, Tang YY. Industrial utilization on bamboo: technical report no. 26. The International Network for Bamboo and Rattan (INBAR), People's Republic of China, 2002.

24. Chaowana P. Bamboo: an alternative raw material for wood and wood-based composites. J Mater Sci Res. 2013;2(2): 90-102.

25. Jiang ZH. Bamboo and rattan in the world. People's Republic of China: China forestry publishing house, 2007.

26. Lobovikov M, Paudel S, Piazza M, Ren H, Wu J. World bamboo resources - a thematic study prepared in the framework of the Global Forest Resources Assessment 2005: non-wood forest products 18 (non-wood forest products). Food and Agriculture Organization of the United Nations (FAO), Rome, Italy, 2007.

27. Gielis J. Future possibilities for bamboo in European agriculture. Oprins Plant Sint-Lenaartsesteenweg. 2002;91:1-10.

28. Kofman PD. Units, conversion factors and formulae for wood for energy. Ireland: Dublin, Council for Forest Research and Development (COFORD) Connects; 2010.

29. Juliana AH, Paridah MT, Rahim S, Nor Azowa I, Anwar UMK. Affect of adhesion and properties of kenaf (Hibiscus cannabinus L.) stem in particleboard performance. J Adhes Sci Technol. 2014;28(6):546-60.

30. Ververis C, Georghiou K, Christodoulakis N, Santas P, Santas R. Fiber dimensions, lignin and cellulose content of various plant materials and their suitability for paper production. Ind Crop Prod. 2004;19:245-54.

31. Abdul Khalil HPS, Ireana Yusra AF, Bhat AH, Jawaid M. Cell wall ultrastructure, anatomy, lignin distribution and chemical composition of Malaysian cultivated kenaf fiber. Ind Crop Prod. 2010;31(1):113-21.

32. Ng SH, Paridah MT, Rosfarizan M, Luqman CA, Choo ACY, Liong YY. Effect of pretreatment process on bioconversion of kenaf (Hibiscus cannabinus L.) core to glucose. Bioresources. 2010;8(2):2010-7.

33. Aisyah HA, Paridah MT, Sahri MH, Anwar UMK, Astimar AA. Properties of medium density fibreboard (MDF) from kenaf (Hibiscus cannabinus L.) core as function of refining conditions. Compos Part B. 2012;44(1):592-6.

34. H'ng PS, Khor BN, Tadasi N, Aini ASN, Paridah MT. Anatomical structures and fibre morphology of new kenaf varieties. Asian J Sci Res. 2009;2(3):161-6. 
35. Munawar SS, Umemura K, Kawai S. Characterization of the morphological, physical, and mechanical properties of seven nonwood plant fiber bundles. J Wood Sci. 2007;53:108-13.

36. KEFI. Properties of principal fibers, 2004. http://www.kenaf-fiber. com/en/infotec-tabella10.asp. Accessed 10 March 2015.

37. Aisyah HA, Paridah MT, Sah̆ri MH, Astimar AA, Anwar UMK. Influence of thermo mechanical pulping production parameters on properties of medium density fibreboard made from kenaf bast. J Appl Sci. 2012;12(6):575-80.

38. Klyosov AA. Wood-plastic composites. Hoboken, New Jersey: Wiley; 2007.

39. Mather RR, Wardman RH. The chemistry of textile fibres. Cambridge: RSC Publishing; 2011.

40. Ramakrishna G, Sundararajan T. Studies on the durability of natural fibres and the effect of corroded fibres on the strength of mortar. Cement Concrete Compos. 2005;27:575-82.

41. Bismarck A, Mishra S, Lampke T. Plant fibers as reinforcement for green composites. In: Mohanty AK, Misra M, Drzal LT, editors. Natural fibers, biopolymer and biocomposites. Florida: Taylor and Francis; 2005.

42. Loh YF, Paridah MT, Hoong YB. Density distribution of oil palm stem veneer and its influence on plywood mechanical properties. $\mathrm{J}$ Appl Sci. 2011;11(5):824-31. This article discusses the feasibility of treated OPT as a raw material for plywood manufacture. This study also highlights that low-grade OPT (palm waste) can be improved by using a resin treatment method.

43. Abdul Khalil HPS, Siti Alwani M, Ridzuan R, Kamarudin H, Khairul A. Chemical composition, morphological characteristics, and cell wall structure of Malaysian oil palm fibers. Polym-Plast Technol Eng. 2008;47(3):273-80. This article highlights the chemical composition, morphology, and cell wall structure of oil palm fibers available in Asia.

44. Abdul Khalil HPS, Siti Alwani M, Mohd Omar AK. Chemical composition, anatomy, lignin distribution, and cell wall structure of Malaysian plant waste fibers. Bioresources. 2006;1(2):220-32.

45. Asiah A, Mohd Razi I, Mohd Khanif Y, Marziah M, Shaharuddin M. Physical and chemical properties of coconut coir dust and oil palm empty fruit bunch and the growth of hybrid heat tolerant cauliflower plant. Pertanika J Trop Agri Sci. 2004;27(2):121-33.

46. Law KN, Wan Rosli WD, Arniza G. Morphological and chemical nature of fiber strands of oil palm empty-fruit-bunch (OPEFB). Bioresources. 2007;2(3):351-62.

47. Hemmasi AH, Samariha A, Tabei A, Nemati M, Khakifirooz A. Study of morphological and chemical composition of fibers from Iranian sugarcane bagasse. Am-Eurasian J Agric Environ Sci. 2011;11(4):478-81.

48. Lam PS, Sokhansanj S, Bi X, Lim CJ, Naimi LJ, Hoque M, et al. Bulk density of wet and dry wheat straw and switchgrass particles. Appl Eng Agric. 2008;24(3):351-8.

49. Kasmani JE, Samariha A. Some chemical and morphological properties of wheat straw. Middle-East J Sci Res. 2011;8(4): 823-5.

50. Singh S, Dutt D, Tyagi CH. Complete characterization of wheat straw (Triticum aestivum PWB-343 L. Emend. Fiori \& Paol.) - a renewable source of fibres for pulp and paper making. Bioresources. 2010;6(1):154-77.

51. Adapa P, Tabil L, Schoenau G. Compression characteristics of selected ground agricultural biomass. Agr Eng Int: the CIGR E J. 2009; 1347(XI):1-19.

52. Sefidgaran R, Resalati H, Kazemi NS. A study of potentials of producing soda pulps from colza straw for making fluting paper. Iranian J Nat Resour. 2005;2:433-46.

53. Yousefi H. Canola straw as a bio-waste resource for medium density fibreboard (MDF) manufacture. Waste Manag. 2009;29:2644-8.
54. Rao KMM, Rao KM. Extraction and tensile properties of natural fibers: Vakka, date and bamboo. Compos Struct. 2007;77:288-95.

55. Li ZH, Wang L, Wang X. Cement composites reinforced with surface modified coir fibers. J Compos Mater. 2007;41(12): 1445-57.

56. Razak W, Mohd Tamizi M, Shafiqur R, Mohammed AS, Othman $\mathrm{S}$, Mahmud S, et al. Relationship between physical, anatomical and strength properties of 3-year-old cultivated tropical bamboo Gigantochloa scortechinii. ARPN J Agric Bio Sci. 2012;7(10): 782-91.

57. Li X. Physical, chemical, and mechanical properties of bamboo and its utilization potential for fiberboard manufacturing. Master Thesis: Louisiana State University and Agriculture and Mechanical College; 2004.

58. Bond B. Wood identification for hardwood and softwood species native to Tennessee, The University of Tennessee Agricultural Extension Service, 2002. http://trace.tennessee.edu/utk_agexfores/10. Accessed 10 March 2015.

59. Tsoumis G. Science and technology of wood: structure, properties and utilization. New York: Van Nostrand Reinhold; 1991. p. 494.

60. Rydholm SA. Pulping processes. Inc. New York: Wiley; 1965. p. 49-52.

61. Saiful Azry SOA. Evaluation of properties of 4-year old rubberwood clones RRIM 2000 series for particleboard manufacture. MSc. Thesis: Universiti Putra Malaysia, Selangor, Malaysia; 2007.

62. Blackburn RS. Biodegradable and sustainable fibres. Cambridge: Woodhead Publishing Series in Textiles: 47, The Textile Institute; 2005.

63. Abdul Khalil HPS. Acetylated plant fibre reinforced composites. $\mathrm{PhD}$ Thesis. School of Agricultural and Forest Sciences, University of Wales, Bangor, Gwynedd, United Kingdom, 1999.

64. Mwaikambo LY, Ansell MP. Mechanical properties of alkali treated plant fibres and their potential as reinforcement materials.1. Hemp fibres. J Mater Sci. 2006;41:2483-96.

65. Okubo K, Yuzo TF. Development of bamboo-based polymer composites and their mechanical properties. Compos Part A. 2004;35: 377-83.

66. Bolton AJ. Natural fibres for plastic reinforcement. Mater Technol. 1994;9:12-20.

67. Zakiah A, Hamami S, Paridah MT. Oil palm trunk fiber as a biowaste resource for concrete reinforcement. Int J Mech Mater Eng. 2010;5(2):199-207.

68. Yusoff MZM, Sapuan MS, Napsiah I, Riza W. Mechanical properties of short random oil palm fibre reinforced epoxy composites. Sains Malaysiana. 2010;39(1):87-92.

69. Cao Y, Shibata S, Fukumoto I. Mechanical properties of biodegradable composites reinforced with bagasse fibre before and after alkali treatments. Compos Part A. 2006;37:423-9.

70. O'Dogherty MJ, Huber JA, Dyson J, Marshall CJ. A study of the physical and mechanical properties of wheat straw. J Agric Eng Res. 1995;62(2):133-42.

71. Perry DR. (conv.), Identification of textile materials. Manara Printing Services: The Textile Institute, London; 1975.

72. Horn RA, Setterholm VC. Fiber morphology and new crops. In: Janick J, Simon JE, editors. Advances in new crops. Portland: Timber Press; 1990. p. 270-5.

73. Sobczak L, Lang RW, Haider A. Polypropylene composites with natural fibers and wood-general mechanical property profiles. Compos Sci Technol. 2012;72:550-7.

74. John MJ, Anandjiwala RD. Recent developments in chemical modification and characterization of natural fiber-reinforced composites. Polym Compos. 2007;29(2):187-207.

75. MATEBASE. Datasheet, European spruce. 2010. 
76. Mohanty AK, Misra M, Hinrichsen G. Biofibres, biodegradable polymers and biocomposites: an overview. Macromol Mater Eng. 2000;276-277:1-24.

77. Fu SY, Lauke B, Mäder E, Yue CY, Hu X. Tensile properties of short-glass-fiber- and short carbon-fiber-reinforced polypropylene composites. Compos Part A. 2000;31(10):1117-25.

78. Nordahlia AS, Anwar UMK, Hamdan H, Abd Latif M, Mahanim SMA. Anatomical, physical and strength properties of Shizostachyum brachycladum (Buluh lemang). J Bamboo Rattan. 2011;10(3\&4):111-22.

79. Lee YH. Malaysian timbers-rubberwood. Malaysian Forest Service Trade Leaflet No. 58. Kepong, Malaysia, Malaysian Timber Industry Board, 1982.

80. Matan N, Kyokong B. Effect of moisture content on some physical and mechanical properties of juvenile rubberwood (Hevea brasiliensis Muell. Arg.) Songklanakarin. J Sci Technol. 2003;25(3):327-40.

81. MTIB. 100 Malaysian timbers. Malaysian Timber Industry Board, Ministry of Plantation Industry and Commodities. Kuala Lumpur. 284 pp. 2010.

82. Kamke FA. Densified radiata pine for structural composites. Maderas Ciencia y Tecnología. 2006;8(2):83-92.

83. Drzal LT, Madhukar M. Fibre-matrix adhesion and its relationship to composite mechanical properties. J Mater Sci. 1993;28:569610 .

84. Jayamol G, Sreekala MS, Sabu T. A review on interface modification and characterization of natural fiber reinforced plastic composites. Polym Eng Sci. 2001;41(9):1471-85.

85. Fan M. Characterization and performance of elementary hemp fibre: factors influencing tensile strength. Bioresources. 2010;5(4):2307-22.

86. Franco PJH, Gonzalez AV. Fiber-matrix adhesion in natural fiber composite. In: Mohanty AK, Misra M, Drzal LT, editors. Natural fibers, biopolymer and biocomposites. Florida: Taylor and Francis; 2005.

87. Kabir MM, Wang H, Aravinthan T, Cardona F, Lau KT. Effects of natural fibre surface on composite properties: a review, pp 94-99. Queensland University of Technology. In Proceedings of the 1st International Postgraduate Conference on Engineering, Designing and Developing the Built Environment for Sustainable Wellbeing. 2011.

88. Bledzki AK, Gassan J. Composites reinforced with cellulose based fibres. Polym Sci. 1999;24:221-74.

89. Keener TJ, Stuart RK, Brown TK. Maleated coupling agents for natural fibre composites. Compos Part A. 2004;35:357-62.

90. Mohanty AK, Misra M, Drza LT, editors. Natural fibers, biopolymer and biocomposites. Florida: Taylor and Francis; 2005.

91. Zafeiropoulos NE. Properties and performance of natural-fibre composites. University of Ioannina, Greece: Woodhead Publishing Limited. Pp 127-162; 2008 .

92. Sreekala MS, Kumaran MG, Thomas S. Oil palm fibers: morphology, chemical composition, surface modification, and mechanical properties. J Appl Polym Sci. 1997;66(5):821-35.

93. Tserki V, Zafeiropoulos NE, Simon F, Panayiotou C. A study of the effect of acetylation and propionylation surface treatments on natural fibres. Compos Part A: Appl Sci Manuf. 2005;36(8):1110 8.

94. Norul Izani MA, Paridah MT, Anwar UMK, Mohd Nor MY, H'ng PS. Effect of fibre treatment on morphology, tensile and thermogravimetric analysis of oil palm empty bunches fibres. Compos Part B. 2013;45:1251-7.

95. Norul Izani MA, Paridah MT, Mohd Nor MY, Anwar UMK. Properties of medium-density fibreboard (MDF) made from treated empty fruit bunch of oil palm. J Trop Forest Sci. $2013 ; 25(2): 175-83$.
96. Anwar UMK, Paridah MT, Hamdan H, Zaidon A, Roziela Hanim A, Nordahlia AS. Adhesion and bonding properties of low molecular weight phenol formaldehyde-treated plybamboo. J Trop Forest Sci. 2012;24(3):379-86.

97. Blomquist RF, Christiansen AW, Gillespie RH, Myers GE. Adhesive bonding of wood and other structural materials. Volume III, Clark C. Heritage Memorial Series on Wood, Madison, Wis; 1981; 12-110.

98. Wellons JD. Wettability and gluability of Douglas-fir veneer. Forest Prod J. 1980;30(7):53-5.

99. Hague J, Mclauchlin A, Richard Q. Agri-materials for panel products: a technical assessment for their viability. In Proceedings of the 32th International Particleboard/Composite Materials Symposium. United States.: Washington State University; 1998.

100. Han GP, Deng J, Zhang S, Bicho P, Wu Q. Effect of steam explosion treatment on characteristics of wheat straw. Ind Crop Prod. 2010;31:28-33.

101. Nor Hafizah AW, Paridah MT, Hoong YB, Zaidon A, Nor Yuziah MY, Anwar UMK. Mohd Hamami Shahri. Adhesion characteristics of phenol formaldehyde pre-preg oil palm stem veneers. Bioresources. 2012;7(4):4545-62.

102. Halvarsson $\mathrm{S}$, Edlund $\mathrm{H}$, Norgren $\mathrm{M}$. Wheat straw as raw material for manufacture of medium density fibreboard (MDF). Bioresources. 2010;5(2):1215-31.

103. Mantanis G, Berns J. Strawboards bonded with urea formaldehyde resins. 35th International Particleboard/Composite Mat. Symp. WSU, Pullmann, USA. 1-19. 2001.

104. Zawawi I, Astimar AA, Ridzuan R, Anis M, Lee SJ. Effect of refining parameters on medium density fibreboard (MDF) properties from oil palm trunk (Elaeis guineensis). Open J Compos Mater. 2013;3:127-31.

105. Zawawi I, Astimar, AA, Ridzuan R, Anis M, Ridzuan R, Ropandi M. Production of medium density fibreboard (MDF) from oil palm fronds and its admixture. MPOB Information Series, 2012.

106. Harmaen AS, Jalaluddin H, Paridah MT. Properties of medium density fibreboard panels made from rubberwood and empty fruit bunches of oil palm biomass. J Compos Mater. 2012;47(22): 2875-83.

107. Das AK, Islam MA, Shams MI, Hannan MO, Biswas SK. Physical and mechanical properties of UF bonded and without binding agent bagasse MDF. Asian J Appl Sci. 2014;7(1):45-50.

108. Ye XP, Julson J, Kuo M, Womac A, Myers D. Properties of medium density fiberboards made from renewable biomass. Bioresour Technol. 2007;98:1077-84.

109. Zaidon A, Sabiha S, Rasmina H, Mohd Nor MY, Sahri MH. Characteristics of pulp produced from refiner mechanical pulping of tropical bamboo (Gigantochloa scortechinii). Pertanika J Trop Agric Sci. 2010;33(2):251-8.

110. Kalaycioglu H, Nemli G. Producing composite particleboard from kenaf (Hibiscus cannabinus L.) stalks. Ind Crop Prod. 2006;24: 177-80.

111. Juliana AH, Paridah MT, Choo ACY, Zaidon A. Effect of kenaf parts on the performance of single-layer and three-layer particleboard made from kenaf and rubberwood. Bioresources. 2014;9(1): 1401-16.

112. Nikvash N, Kraft R, Kharazipour A, Euring M. Comparative properties of bagasse, canola and hemp particleboards. Eur J Wood Prod. 2010;68:323-7.

113. Papadopoulos AN, Hague JRB. The potential for using flax (Linum usitatissimum L.) shiv as a lignocellulosic raw material for particleboard. Ind Crop Prod. 2003;17:143-7.

114. Hashim R, Saari N, Sulaiman O, Sugimoto T, Hiziroglu S, Sato M, et al. Effect of particle geometry on the properties of binderless particleboard manufactured from oil palm trunk. Mater Des. 2010;31(9):4251-7. 
115. Saiful Azry SOA, Norfaryanti K. Paridah MT. Juliana AH: Aisyah HA. Oil palm frond as raw material for particleboard manufacturing. In Forest Malaysian Forest Goods and Services II. UPM Press; 2014.

116. Zaidon A, Norhairul Nizam AM, Mohd Nor MY, Abood F, Paridah MT, Nor Yuziah MY, et al. Properties of particleboard made from pretreated particles of rubberwood, EFB and rubberwood-EFB blend. J Appl Sci. 2007;7(8):1145-51.

117. Boquillon N, Elbez G, Schonfeld U. Properties of wheat straw particleboards bonded with different types of resin. J Wood Sci. 2004;50:230-5.

118. Melo RR, Stangerlin DM, Santana RRC, Pedrosa TD. Physical and mechanical properties of particleboard manufactured from wood. Bamboo Rice Husk Mater Res. 2014;17(3):682-6.

119. Bektas I, Guler C, Kalaycioglu H, Mengeloglu F, Nacar M. The manufacture of particleboards using sunflower stalks (Helianthus annuиs L.) and poplar wood (Populus alba L.). J Compos Mater. 2005;39:467-73.

120. Freytag R, Donze J. Handbook of fiber science and technology, Vol. 1, Part A: Lewin M, Sello SB. (Eds.). New York: Marcel Dekker; 1983.

121. Anwar UMK, Paridah, MT, Hamdan H, Abd Latif M, Zaidon A. Adhesion and bonding properties of plybamboo manufactured from Gigantochloa scortechinii. Am J Appl Sci (Special Issue). 2005: 53-58.
122. Sulastiningsih IM, Nurwati, Sutigno A. Pengaruh Lapisan Kayu Terhadap Sifat Bambu Lamina. J Penelitian Hasil Hutan. 2009;23: $15-22$.

123. Rahman KS, Nazmul Alam DM, Islam MN. Some physical and mechanical properties of bamboo mat-wood veneer plywood. ISCA J Bio Sci. 2012;1(2):61-4.

124. Srivaro S, Chaowana P, Matan N, Kyokong B. Lightweight sandwich panel from oil palm wood core and rubberwood veneer face. J Trop Forest Sci. 2014;26(1):50-7.

125. Hashim R, Sarmin SN, Sulaiman O, Yusof LHM. Effects of cold setting adhesives on properties of laminated veneer lumber from oil palm trunks in comparison with rubberwood. European J Wood and Wood Prod. 2011;69(1):53-61.

126. Wang Z, Guo W. Laminated panel manufacture of two kinds of bamboo for architecture material and property comparison. INBAR, No. 48, 6 pp. 2003.

127. Laufenberg T, Ayrilmis N, White R. Fire and bending properties of blockboard with fire retardant veneers. Holzals Roh-und Werks. 2006;64:137-43.

128. Freeman H. Properties of wood and adhesion. Forest Prod J. 1959;9:451-8.

129. Bhat IUH, Mustafam MT, Mohmod AL, Abdul Khalil HPS. Spectroscopic, thermal and anatomical characterization of cultivated bamboo (Gigantocloa spp.). Bioresources. 2011;6(2):175263. 